OECD Economics Department Working Papers No. 1511

\title{
Resource curse in oil exporting countries
}

\section{Evgeny Kakanov,}

\section{Hansjörg Blöchliger, Lilas Demmou}

https://dx.doi.org/10.1787/a5012a3d-en 
ECO/WKP(2018)59

Unclassified

English - Or. English

16 August 2021

ECONOMICS DEPARTMENT

Cancels \& replaces the same document of 22 October 2018

\section{RESOURCE CURSE IN OIL EXPORTING COUNTRIES}

\section{ECONOMICS DEPARTMENT WORKING PAPERS No. 1511}

By Evgeny Kakanov, Hansjörg Blöchliger and Lilas Demmou

OECD Working Papers should not be reported as representing the official views of the OECD or of its member countries. The opinions expressed and arguments employed are those of the author(s).

Authorised for publication by Álvaro Pereira, Director, Country Studies Branch, Economics Department.

All Economics Department Working Papers are available at www.oecd.org/eco/workingpapers.

JT03480057 
OECD Working Papers should not be reported as representing the official views of the OECD or of its member countries. The opinions expressed and arguments employed are those of the author(s).

Working Papers describe preliminary results or research in progress by the author(s) and are published to stimulate discussion on a broad range of issues on which the OECD works.

Comments on Working Papers are welcomed, and may be sent to the Economics Department, OECD, 2 rue AndréPascal, 75775 Paris Cedex 16, France.

All Economics Department Working Papers are available at www.oecd.org/eco/workingpapers

A previous version of this paper was released on 8 October 2018. This version provides additional bibliographical references, improves readability with a more precise wording and corrects an erratum in the data description.

This document and any map included herein are without prejudice to the status of or sovereignty over any territory, to the delimitation of international frontiers and boundaries and to the name of any territory, city or area.

The statistical data for Israel are supplied by and under the responsibility of the relevant Israeli authorities. The use of such data by the OECD is without prejudice to the status of the Golan Heights, East Jerusalem and Israeli settlements in the West Bank under the terms of international law.

On 3 May 2018, the OECD Council invited Lithuania to become a Member. At the time of preparation, the deposit of Lithuania's instrument of accession to the OECD Convention was pending and therefore Lithuania does not appear in the list of OECD Members and is not included in the OECD zone aggregates.

On 25 May 2018, the OECD Council invited Colombia to become a Member. At the time of preparation, the deposit of Colombia's instrument of accession to the OECD Convention was pending and therefore Colombia does not appear in the list of OECD Members and is not included in the OECD zone aggregates.

\section{(C) OECD (2018)}

You can copy, download or print OECD content for your own use, and you can include excerpts from OECD publications, databases and multimedia products in your own documents, presentations, blogs, websites and teaching materials, provided that suitable acknowledgment of OECD as source and copyright owner is given. All requests for commercial use and translation rights should be submitted to PubRights@oecd.org. 


\section{ABSTRACT/RÉSUMÉ \\ Resource curse in oil exporting countries}

This paper provides a comprehensive analysis of the "resource curse" phenomenon, i.e. the negative impact of the natural resource abundance on the long-term economic development, for a set of oil exporting countries. It distinguishes between two potential drivers of the resource curse: oil dependence and oil price shocks, and it investigates whether the resource curse depends on a country's institutional and macroeconomic environment. The empirical analysis relies on a panel of 24 oil exporters between 1982 and 2012 and an error correction model. The paper provides robust evidence in favour of the resource curse hypothesis: a 10-percentage point increase in the oil export share is associated with a 7\% lower GDP per capita in the long run. Oil price shocks appear to have an asymmetric impact in the short run: the growth effect is positive when oil prices rise, while no statistically significant effect is observed when they fall. There is an indirect evidence that the impact of an oil price shock is partly offset by fiscal policies, particularly in countries with high oil dependence. In the long run, an oil price shock does not appear to have a statistically significant impact on GDP. Finally, exchange rate regimes seem to play a role: a fixed exchange rate regime is associated with a higher GDP, potentially due to the presence of sovereign wealth or stabilisation funds. Most of oil exporters with a fixed exchange rate regime have such funds allowing them to actively use fiscal policies to counter oil price shocks.

JEL Classification: Q32, E02, K00

Keywords: oil dependence, resource curse, oil price shocks, institutions, exchange rate

$$
* * * * *
$$

\section{Malédiction des ressources naturelles dans les pays exportateurs du pétrole}

Cette étude fournit une analyse globale du phénomène dit de «la malédiction des ressources naturelles », qui suppose que l'abondance en matières premières a un impact négatif sur le dévéloppement économique à long terme, pour un groupe de pays exportateurs du pétrole. Deux déterminants de la malédiction des ressources sont en particulier distingués : la dépendance aux ressources pétrolières et les chocs de prix du pétrole. Cet article examine la possibilité que la «malédiction des ressources naturelles » dépende de l'environnement institutionnel et macroéconomique. L'analyse empirique repose sur un panel de 24 pays exportateurs de pétrole entre 1982 et 2012 et un modèle de correction des erreurs. L'étude fournit des éléments probants en faveur de l'hypothèse de « la malédiction des ressources naturelles » : une augmentation de 10 points de pourcentage de la part des exporations du pétrole est associée à un PIB par habitant $7 \%$ plus bas à long terme. Les chocs de prix du pétrole se révèlent avoir un impact asymétrique à court terme : l'effet sur la croissance est positif quand le prix du pétrole augmente mais aucun effet statistiquement significatif n'est trouvé quand le prix baisse. Les résultats suggèrent que l'impact du choc de prix du pétrole est en partie neutralisé par des politiques budgétaires, notamment dans les pays avec une dépendance au pétrole importante. Enfin, le régime de change semble jouer un rôle : le taux de change fixe est associé à un niveau de PIB supérieur, potentiellement dû à la présence des fonds souverains de stabilisation. La plupart des exportateurs du pétrole avec un régime de change fixe ont de tels fonds leur permettant d'utiliser activement des politiques budgétaires afin de contrer les chocs de prix du pétrole.

Classification JEL : Q32, E02, K00

Mots clefs : la dépendance au pétrole, la malédiction des ressources naturelles, les chocs de prix du pétrole, les institutions, le taux de change 


\section{Table of contents}

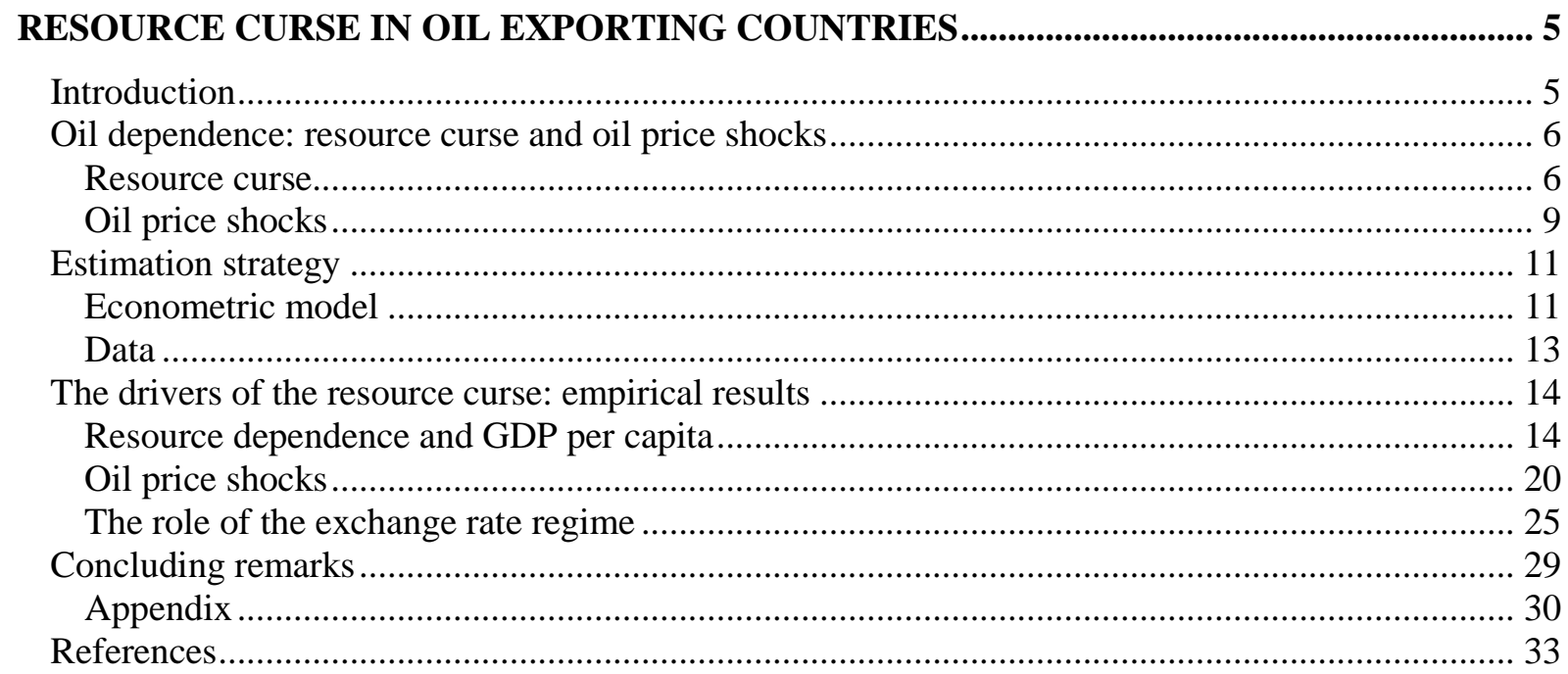

\section{Tables}

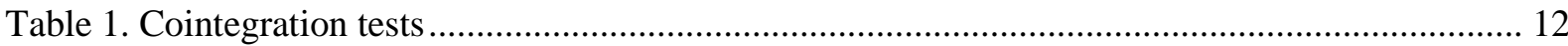

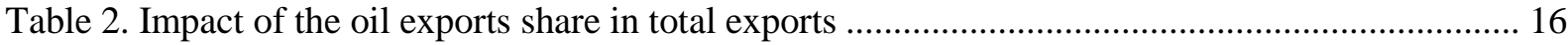

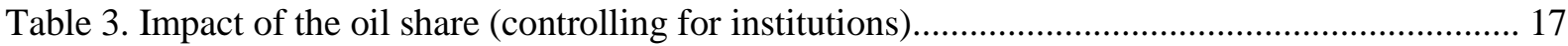

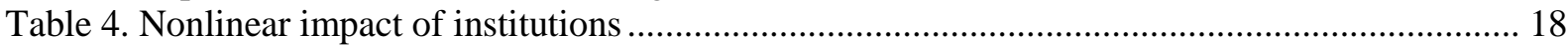

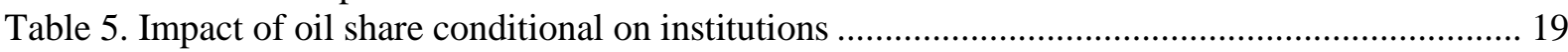

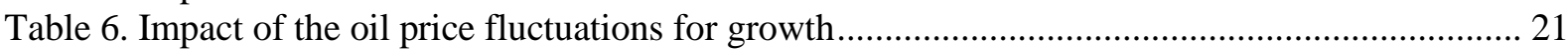

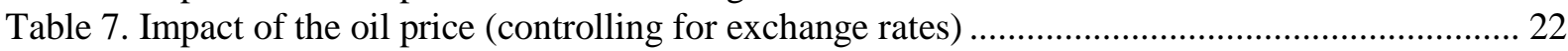

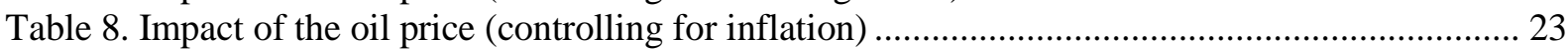

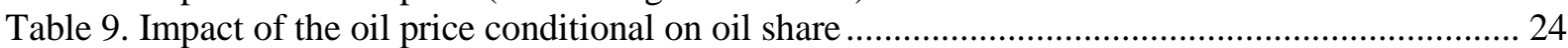

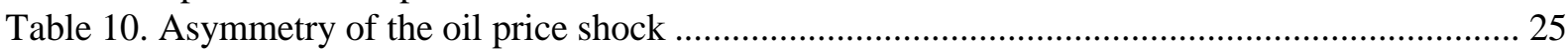

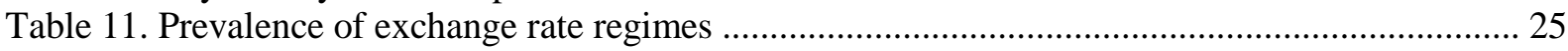

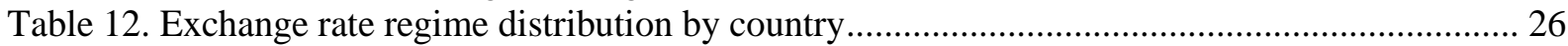

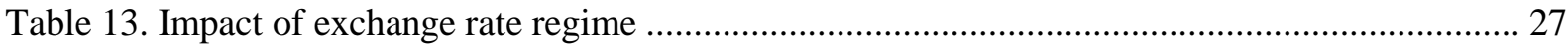

Table 14. Impact of exchange rate regime controlling for oil price ...................................................... 28

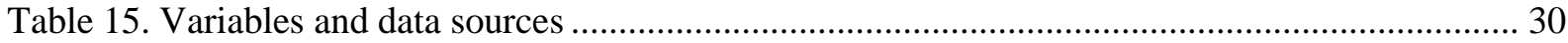

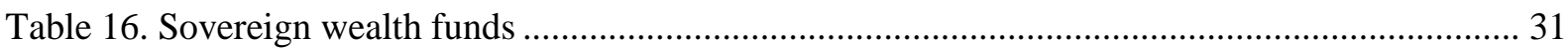

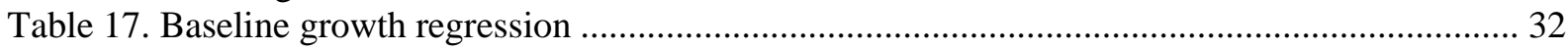

Figures

Figure 1. Average growth rates of real GDP per capita and average oil exports share in total exports .. 5 Figure 2. Average judicial independence and average oil exports share in total exports ....................... 8 Figure 3. Average growth rates of GDP per capita and average judicial independence ......................... 9

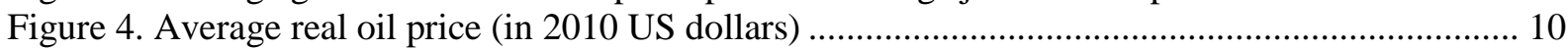
Figure 5. Difference in the real GDP per capita growth rates (2015 vs 2013), percentage points ........ 11

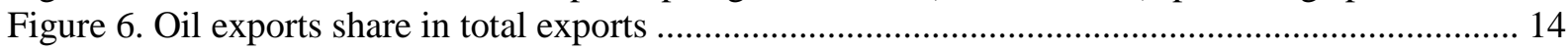




\title{
RESOURCE CURSE IN OIL EXPORTING COUNTRIES
}

\author{
by Evgeny Kakanov, Hansjörg Blöchliger and Lilas Demmou ${ }^{1}$
}

\section{Introduction}

A disquieting set of evidence suggests that the relationship between a country's natural resource dependence and its long-term economic development is negative. More specifically, over the past 20 years a larger dependence on oil exports was on average associated with lower growth for oil-exporting countries (Figure 1). This stylised fact is often described as resource curse, pointing at the paradox that countries rich in coveted natural resources may fare poorly in economic terms. A large body of theoretical literature suggests various channels towards this low-growth trap, ranging from structural factors such as a lack of innovation and productivity growth in the natural resource sector, institutional factors such as weak rule of law and property rights in resource-rich economies, or else macroeconomic factors such as resource price fluctuations and their drag on economic and fiscal stability, sometimes exacerbated by an inappropriate exchange rate regime. However, empirical evidence on the drivers of the resource curse is scarce.

Figure 1. Average growth rates of real GDP per capita and average oil exports share in total exports

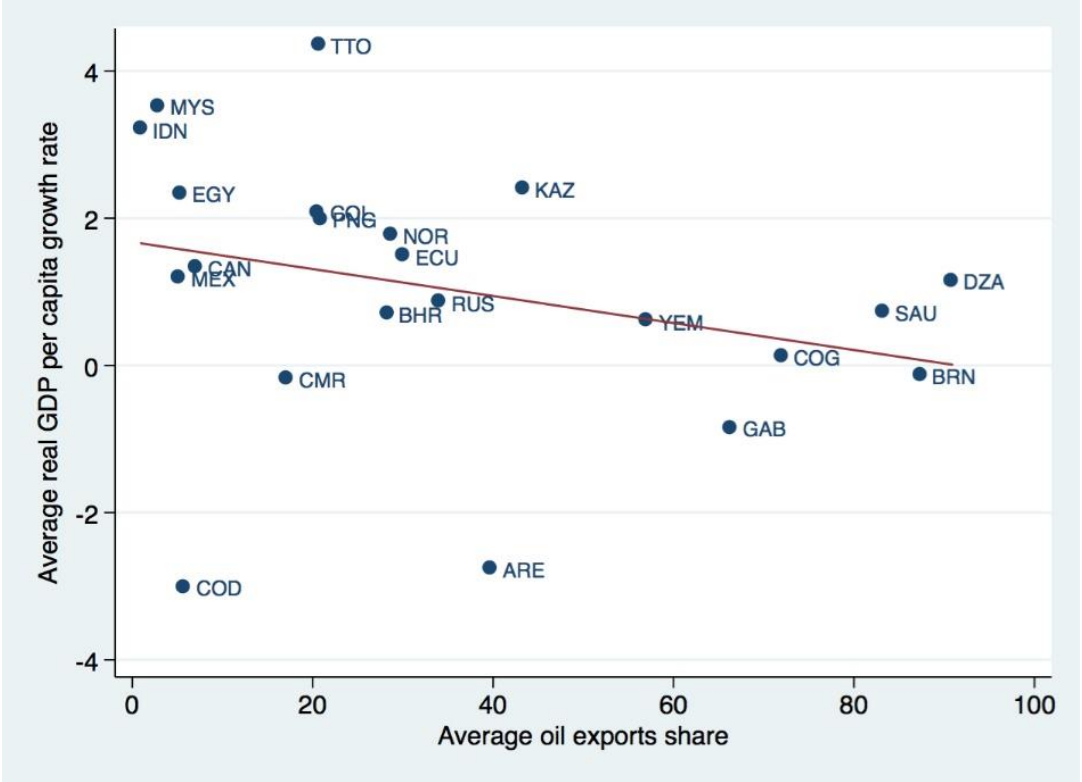

Note: The averages are computed over 1991 to 2012.

Source: Authors' calculations based on the IMF and World Bank data.

${ }^{1}$ The authors are grateful to Oguzhan Akgun, Balazs Egert, Dennis Dlugosch, Jean-Marc Fournier, Manav Frohde, Claude Giorno and Piritta Sorsa for their valuable comments and Carolina Gonzalez for providing editorial assistance. 
This paper provides a novel empirical analysis linking resource dependence of a country to its short- and long-term economic performance. It makes three contributions to the literature on resource curse. First, it assesses oil dependence in a comprehensive manner, taking into account the institutional and macroeconomic environment of oil exporting countries. In particular, the role of institutional quality, fiscal policy and the exchange rate regime for economic development are studied. Second, the paper analyses, within a common framework, both the short- and the long-term GDP effect of oil dependence and of oil price shocks. The third contribution relates to the empirical approach: unlike most other papers, this paper uses panel data allowing for more robust estimation by better controlling for potential omitted variable bias, notably through the use of time and country fixed effects ${ }^{2}$.

The main results of the paper are:

- Oil dependence has a negative effect on the long run GDP per capita, confirming the resource curse hypothesis. A 10-percentage point increase in the oil export share is associated with a 7\% lower GDP per capita in the long run.

- Mitigating the negative impact of oil dependence looks difficult. There is little evidence that, broadly speaking, higher quality institutions help avoid resource curse. More specifically, institutions seem to have a non-linear impact: a higher quality of institutions has a positive effect on GDP only when institutional quality is already high, but when quality is low the effect is negative.

- A positive oil price shock has a significant positive short-term growth effect for oil exporters while an oil price decline has no effect. A $10 \%$ increase in the oil price would lead to a contemporary $0.29 \%$ rise in GDP per capita on average. Oil price shocks seem to be partially offset by fiscal policies suggesting some kind of counter-cyclical stabilisation policy in place. Moreover and little surprisingly, the higher oil dependence, the more pronounced the effect of the shock. In the long run, oil price shocks have no statistically significant effect on GDP.

- In the long run a fixed exchange rate regime is associated with a higher GDP, potentially due to the presence of sovereign wealth or stabilisation funds. Most of the oil exporting countries in the sample have such funds allowing them to actively use fiscal policies to counter oil price shocks.

The paper is organised as follows. Section 2 elaborates on the mechanisms linking oil dependence and economic development. Section 3 presents our econometric model, the data and discusses specification issues. Section 4 presents the results. Data sources are displayed in the Appendix.

\section{Oil dependence: resource curse and oil price shocks}

\section{Resource curse}

The term "resource curse", coined by Auty and Warhurst (1993), refers to the paradox that in the long run, countries rich in natural resources perform worse economically than

${ }^{2}$ Only few papers use such data. See for instance Collier and Goderis (2007), Cavalcanti et al. (2011; 2015), Arezki and Gylfason (2011). Kilian (2009), Peersman and Van Robays (2012) use countryspecific VAR analysis. 
countries where natural resources are scarce. The literature has suggested numerous explanations to the resource curse phenomena ${ }^{3}$. First, high resource dependence results in crowding out of the tradable manufacturing sector, theoretically formalised by Matsuyama (1992) for the agricultural sector and extended by Sachs and Warner (1995) to the case of natural resources in general. In their framework, the economy has three sectors: a tradable resource sector, a tradable non-resource manufacturing sector and a non-traded sector. Only the manufacturing sector is assumed to innovate resulting in labour-augmenting technological change. The greater the natural resource endowment and the revenues that a country receives from it, the greater the domestic demand for non-traded sector goods. As these goods cannot be imported, their prices tend to rise which leads to a greater allocation of labour and capital to the non-traded sector, reducing the stock of labour and capital inputs available for manufacturing. As only the manufacturing sector is a locus of innovation and technological progress, higher resource dependence and in turn a smaller manufacturing sector dampen economic growth.

Second, rent-seeking behaviour in resource rich countries may weaken institutions such as property rights or political accountability which are believed to be fundamental to long term growth (Frankel, 2012) ${ }^{4}$. Figure 2 depicts this negative relationship between resource dependence and a measure of institutional quality (here an index of judicial independence from Linzer \& Staton, 2015). Resource rents also free governments from the need to tax their citizens and thus from the need of accountability and ultimately democracy as a counterpart, known to have a positive long run impact on GDP (Acemoglu et al., 2014). Resource rents may make authoritarian regimes more stable and durable. Andersen and Aslaksen (2013) find that wealth derived from natural resources affects political survival in intermediate and autocratic, but not in democratic, polities; and is associated with positive effects on the duration in political office. Some studies (Jensen and Wantchekon, 2004; Ross, 2012) find that the impact of oil on democracy is also conditional: oil stabilises democracies that are wealthy and have strong institutions, but brings down democracies that are poor or have weak institutions.

${ }^{3}$ See Frankel (2012) and Ross (2015) for a detailed overview.

${ }^{4}$ The term « institutions » is used as in institutional economics, covering issues such as property rights, political accountability, judicial independence, democracy, political rights and civic liberties, etc. 
Figure 2. Average judicial independence and average oil exports share in total exports

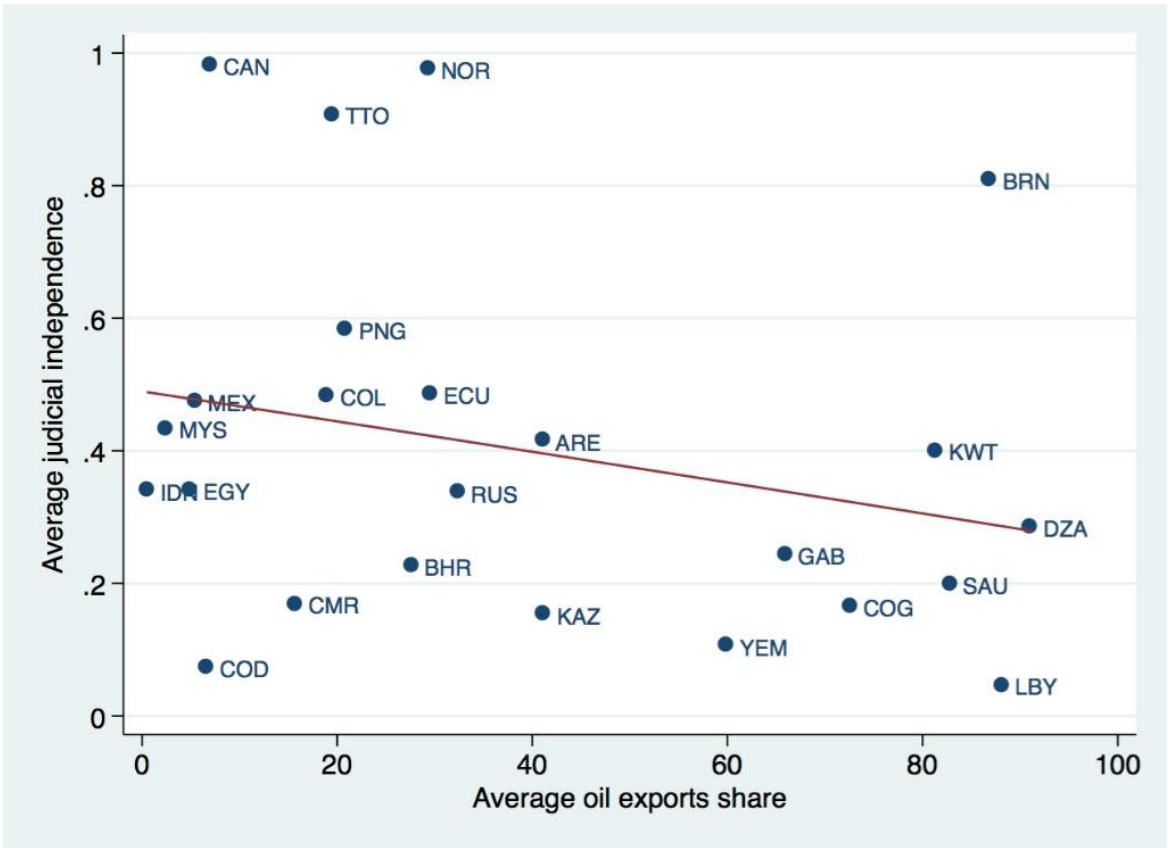

Note: The judicial independence index ranges from 0 to 1 ( 1 being the most independent judiciaries).

Source: Authors' calculations based on the IMF and Linzer \& Staton (2015) data. Averages for years 1992 to 2010 .

\begin{abstract}
Alternatively, bad institutions may themselves foster resource curse. Tornell and Lane (1999) argue that powerful groups compete for fiscal windfalls resulting from commodity booms, for instance. Countries with weak institutions suffer from a "voracity effect" of such competing groups and ultimately experience less growth. Mehlum et al. (2006) also find that the resource curse appears only with "grabber friendly" institutions, more prone to corruption, whereas natural resources with "producer friendly" institutions lead to higher long run wealth. Indeed Figure 3 suggests that the relationship between GDP growth and judicial independence is non-linear, becoming positive at relatively high levels of independence only. A possible explanation could be that increasing judicial independence creates instability and uncertainty when judicial independence is still low. Wiens (2013) combines these two dimensions - initial quality of institutions and their link to natural resources - in a theoretical model and shows that the resource curse can be avoided if institutions to constrain the rulers' policy discretion are set prior to the onset of resource dependence. Otherwise, resource revenues are used to stabilise bad institutions.
\end{abstract}


Figure 3. Average growth rates of GDP per capita and average judicial independence

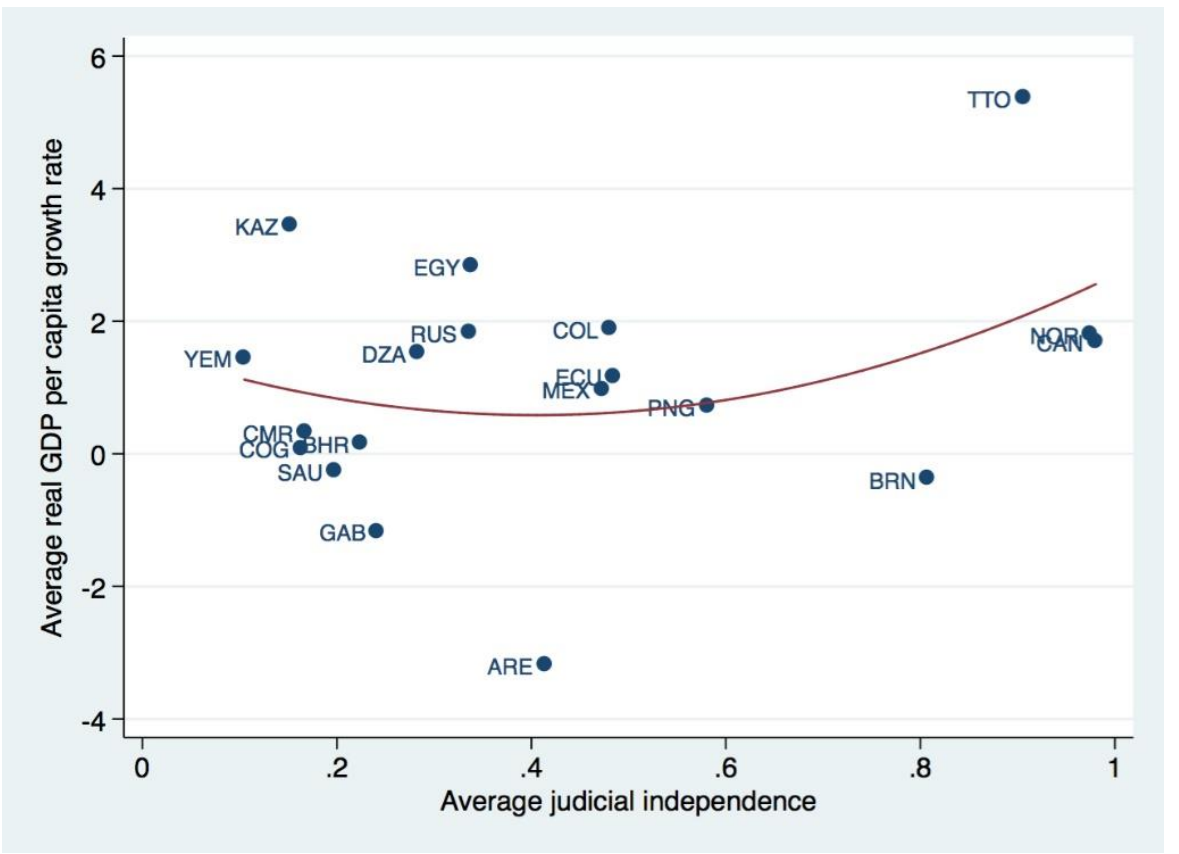

Source: Authors' calculations based on the World Bank and Linzer \& Staton (2015) data. Averages for years 1992 to 2010.

Third, resource wealth and attempts to control it may trigger conflicts and civil wars in countries with fragile institutions and limited democratic tradition. Some theories suggest that, in these cases, resource wealth may weaken states administratively and undermine their ability to prevent rebellions. Others focus on insurgents that could be incited to capture resource stocks to finance rebellions or establish an independent, often ethnically distinct state (Collier and Hoeffler, 1998) ${ }^{5}$.

\section{Oil price shocks}

The volatility of oil and other commodity prices are a major factor for a country falling prey to the resource curse (Figure 4). In particular, commodity price booms may induce the so-called Dutch disease which is a form of resource curse driven by the appreciation of the oil exporters' currency. Higher export revenues result in a higher demand for national currency and its appreciation if exchange rates are flexible. Alternatively, in the case of fixed exchange rates, higher commodity and budget revenues, potentially coupled with lower interest rates - to preserve the exchange rate parity - translate into higher wages and inflation. The real appreciation deteriorates competitiveness of non-commodity exports and profitability of the manufacturing sector, ultimately leading to a de-industrialisation of the economy. This latter reduces long-term growth if productivity growth is higher in the manufacturing sector than in the commodity and non-tradable sectors.

\footnotetext{
${ }^{5}$ See Collier and Hoeffler (1998) for an overview.
} 
Figure 4. Average real oil price (in 2010 US dollars)

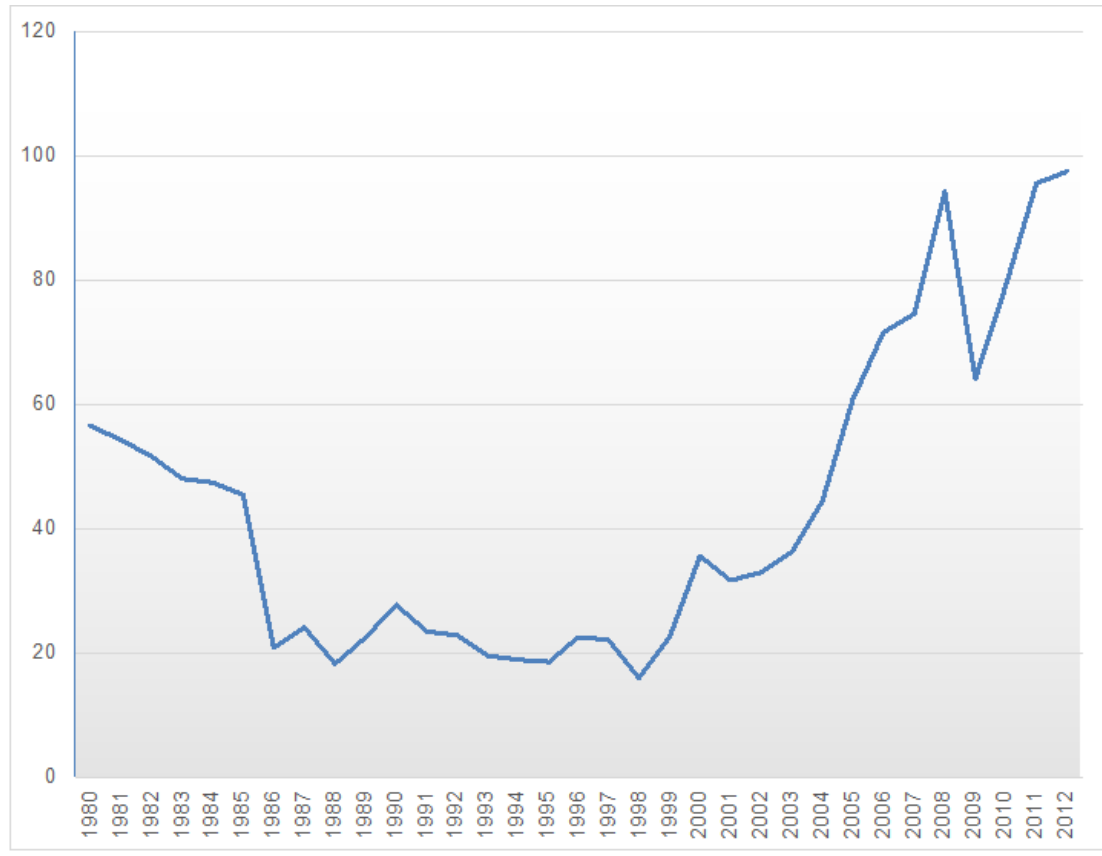

Note: The annual average is computed over WTI, Dubai and Brent oil prices in 2010 US dollars.

Source: World Bank.

The role of oil price fluctuations for growth are likely to depend on the wider macroeconomic framework. The short-term growth impact of a common shock - the decline in prices from US\$ 104 to US\$ 50 per barrel between 2013 and 2015 - varies considerably across oil exporters, suggesting that some countries escape the consequences of oil price fluctuations more easily than others (Figure 5). Fiscal policy might exacerbate or mitigate the impact of oil price shocks. Governments may, for instance, engage in a spending spree during a boom which may become unsustainable once commodity prices are down again. Arezki et al. (2011) indeed find that government spending in commodityexporting countries is often pro-cyclical. When commodity prices burst, countries may also experience an abrupt depreciation of their currency and a surge in inflation leading to a fall in real revenues, consumption and investment. Other channels put the stress on a high commodity price volatility resulting in cyclical shifts of production factors across sectors, their imperfect utilisation due to temporary frictions and induced risks and transaction costs $^{6}$. As such, our empirical approach will put some weight on the role of fiscal policy and exchange rate regimes for the transmission of oil price shocks on economic activity.

\footnotetext{
${ }^{6}$ Cavalcanti et al. (2015) also find that negative impact of commodity price volatility on growth operates through lower accumulation of physical and human capital.
} 
Figure 5. Difference in the real GDP per capita growth rates (2015 vs 2013), percentage points

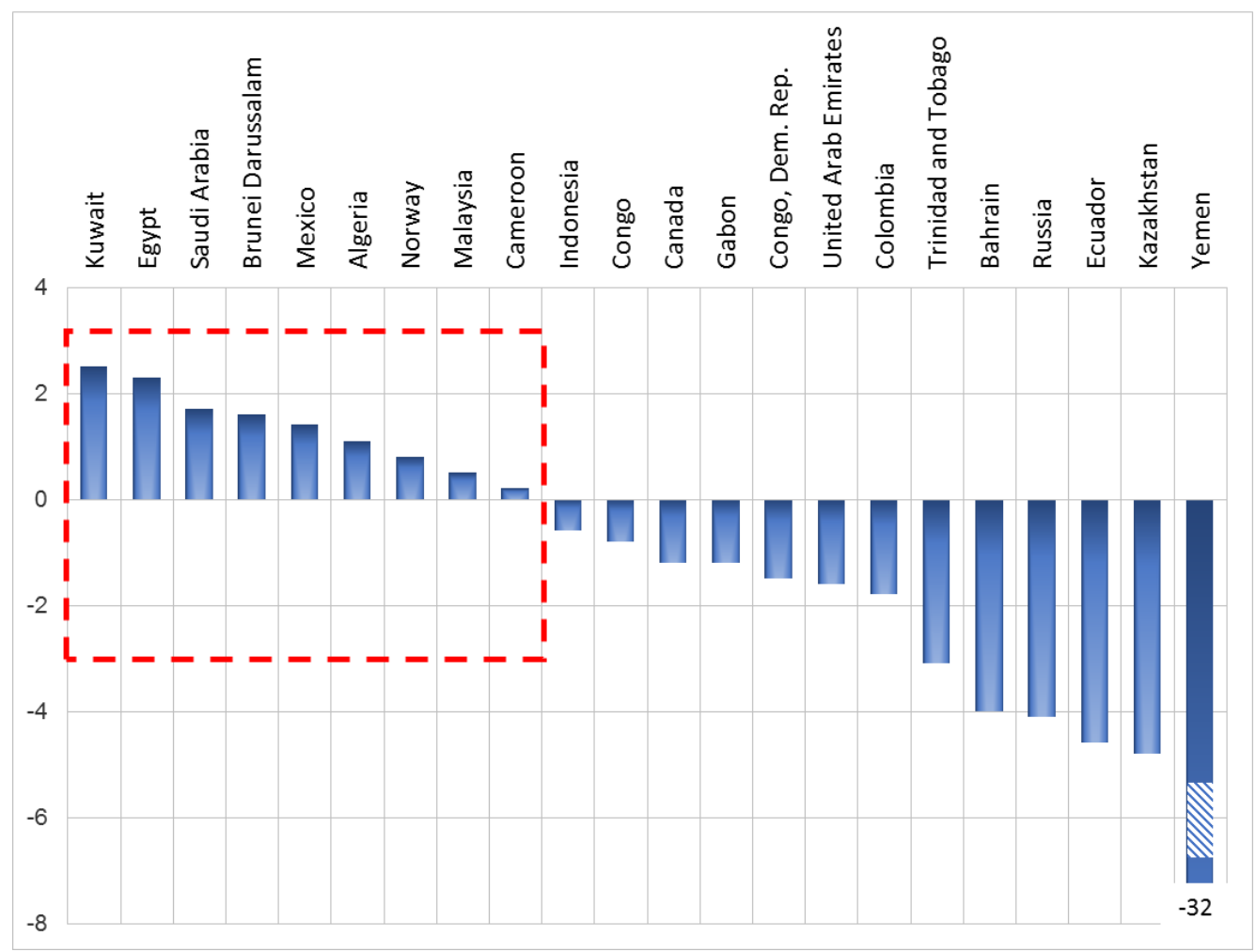

Source: Authors' calculations based on the World Bank data.

\section{Estimation strategy}

\section{Econometric model}

The baseline equation is based on the standard neo-classical human capital augmented model of growth developed by Mankiw et al. (1992). To disentangle short run and long run effects an Error Correction Model (ECM) augmented with contemporary first differences of explanatory variables and one lagged difference of the dependent variable - or equivalently an $\operatorname{ARDL}(2,1)$ - is used. The lag structure is chosen to minimise the Akaike Information Criterion, provided that the lag length is long enough to eliminate the serial correlation in the residuals. As shown in Pesaran (1997), the advantage of ARDL or ECM is that regressors can be treated as strictly exogenous even if they are subject to the same shock as the dependent variable ${ }^{7}$.

Denoting $X$ the variable of interest, the general model reads as follows:

\footnotetext{
${ }^{7}$ See Pesaran (1997) for a mathematical proof.
} 


$$
\begin{aligned}
\Delta \operatorname{GDP}_{i, t}=\alpha_{i}+ & \alpha_{0} \\
& *\left[\operatorname{GDP}_{i, t-1}+b_{1} * \operatorname{INVESTMENT}_{i, t-1}+b_{2} * \text { EDUCATION }_{i, t-1}+b_{3}\right. \\
& \left.* \text { POPULATION }_{i, t-1}+b_{4} *\left(\operatorname{CONTROLS}_{i, t-1}\right)+b_{5} * X_{i, t-1}\right]+\alpha_{1} \\
& * \Delta \operatorname{INVESTMENT}_{i, t}+\alpha_{2} * \Delta \text { EDUCATION }_{i, t}+\alpha_{3} * \Delta \text { POPULATION }_{i, t}+\alpha_{4} \\
& *\left(\Delta \operatorname{CONTROLS}_{i, t}\right)+\alpha_{5} * \Delta X_{i, t}+c_{1} * \Delta \text { GDP }_{i, t-1}+c_{2} * \operatorname{CONFLICT~}_{i, t}+\tau_{t}+\epsilon_{i, t}
\end{aligned}
$$

where GDP is the logarithm of real GDP per capita adjusted for PPP, INVESTMENT is the savings rate proxied by the ratio of gross fixed capital formation to $\mathrm{GDP}^{8}, E D U C A T I O N$ is educational attainment (average years of schooling) in the population over 15 years old, POPULATION is the population size (the logarithm of total population), CONTROLS is a set of control variables (detailed below), CONFLICT is a dummy for minor conflicts with more than 25 but less than 1000 battle deaths, $\alpha_{i}$ and $\tau_{t}$ are country and year fixed effects respectively. Coefficient $\alpha_{1}$ to $\alpha_{5}$ represents the short run or contemporary effects. Long run effects are obtained by dividing the cointegrating equation coefficients $b_{1}$ to $b_{5}$ by $-\alpha_{0}$. Table 1 presents the results of Kao (1999) cointegration tests. Four of five tests reject the null hypothesis of no cointegration. The cointegration ensures that there is effectively a long run relationship between variables, the error term is stationary and $t$-stat are correct, which excludes the risk of spurious results in the panel time series.

Table 1. Cointegration tests

\begin{tabular}{lcc}
\hline Test & Statistic & p-value \\
\hline Modified Dickey-Fuller t & -2.5639 & 0.0052 \\
Dickey-Fuller t & -2.4922 & 0.0063 \\
Augmented Dickey-Fuller t & -2.4918 & 0.0064 \\
Unadjusted modified Dickey-Fuller t & -0.8022 & 0.2112 \\
Unadjusted Dickey-Fuller t & -1.6462 & 0.0499 \\
\hline
\end{tabular}

Note: Results for Kao (1999) cointegration tests. The hypothesis of no cointegration is rejected for 4 out of 5 tests, i.e. where p-values are below 0.05 .

One drawback of using country fixed effects with a lagged dependent variable (as in the ECM case) is the presence of Nickell bias (Nickell, 1981). The literature suggested the use of lagged differences as instruments (GMM estimator), but in the case of nonstationary variables (time series panel) this does not work well as the lagged differences are not valid instruments (Fuertes et al., 2010). However, as shown in Beck and Katz (2011), the fixed effect estimator performs relatively well with $\mathrm{T}=20$ or more (as in our case) and the bias can be considered as negligible.

The robustness of the results to outliers could be a serious concern, as the sample contains very different countries with data of varying quality. To bypass this issue and check the robustness of the coefficients, all results are checked using robust regressions which are based on iterative weighted least squares and allow to weigh every observation dependent on its outlierness. The results of these regressions are qualitatively the same and can be obtained on request.

${ }^{8}$ Following Bloch et al. (2016), the investment to GDP ratio is used instead of the savings rate. In a context of an open economy and possible persistent imbalances, the former should reflect more accurately the accumulation of capital. 


\section{Data}

The scarcity of reliable data for many oil exporting countries is one of the most constraining issues for empirical investigations. The data shortage is apparent in both the number of indicators and their availability across time and countries. This drastically limits the number of viable empirical approaches. The key variables, the dollar values of oil exports and imports of a country, are taken from the IMF World Economic Outlook (WEO) and are available from 1980 to 2012 yearly which therefore defines the time span of the sample ${ }^{9}$.

The following procedure is used to select relevant observations. The share of oil net exports in total exports - henceforth oil share, variable Share - is the measure of oil dependence for every country-year observation. The oil share in total exports (as opposed to the share in GDP) is used for several reasons. First, it helps avoid the problem of reverse causality as the dependent variable is GDP. Second, it reflects better the diversification of an economy as the export structure is often used as an indicator of complexity of an economy (Hausmann and Hidalgo, 2009). Third, it also better reflects the vulnerability to oil price volatility via the exchange rate channel: the greater the share of oil exports in total exports, the higher the volatility of total exports (in value) and thus the higher the exchange rate volatility ${ }^{10}$.

In addition to the annual oil share, the average oil share over the entire period for every country is computed for all countries with at least ten observations. Only country-year observations for which both the oil share is positive and the average oil share is greater than $5 \%$ are retained. Finally, a country-year observation is eliminated if a military conflict with a least 1000 battle deaths occurred or if inflation exceeds $100 \%$ since these very particular events would bias estimates. The final sample contains about 500 observations from 24 countries between 1982 and 2012. Figure 6 presents the oil dependence of these countries measured by the oil exports share in total exports for the last year available (2012) and the average over available years.

The dependent variable, real GDP per capita PPP adjusted, is computed based on real GDP data from the World Bank. The sources and details for other variables are presented in the Appendix.

\footnotetext{
${ }^{9}$ The last available data is from IMF WEO 2013, April which also contains 5 year projections not included in our sample due to particularly strong volatility of oil price and trade values.

${ }^{10}$ Consider two countries with the same oil exports to GDP ratios but different oil exports to total exports ratios. For instance, if oil exports to GDP ratio is equal to $10 \%$ in both countries, total exports to GDP ratio equals $15 \%$ and $30 \%$ in country A and B respectively, the oil exports to total exports ratios would be $67 \%$ (not diversified) and $33 \%$ (diversified) respectively. This would obviously imply very different impacts on exchange rate volatility.
} 
Figure 6. Oil exports share in total exports

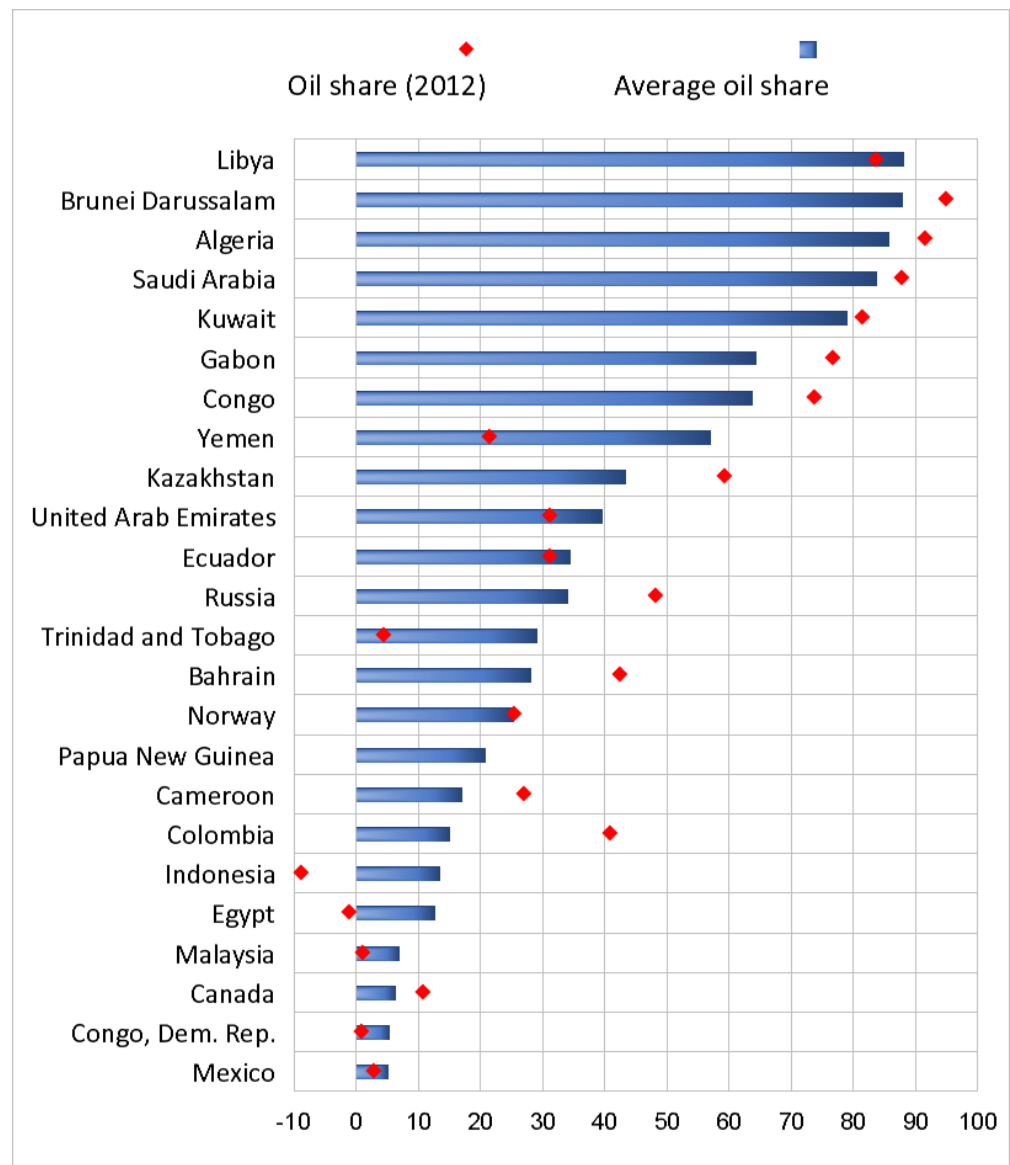

Note: Oil share for Libya in 2012 is based on 2010 figures as no data are available after.

Source: Authors' calculations based on the IMF data.

The drivers of the resource curse: empirical results

\section{Resource dependence and GDP per capita}

The following equation is estimated ${ }^{11}$ to measure the impact of resource dependence:

$$
\begin{aligned}
& \Delta Y_{i, t}=\alpha_{i}+\alpha_{0} *\left[Y_{i, t-1}+b_{1} * I N V E S T_{i, t-1}+b_{2} * E D U M_{i, t-1}+b_{3} * P O P_{i, t-1}+b_{4}\right. \\
& \left.*\left(\text { CONTROLS }_{i, t-1}\right)+b_{5} * O I L_{-} S_{i, t-1}\right]+\alpha_{1} * \Delta I N V E S T_{i, t}+\alpha_{2} \\
& * \Delta E D U M_{i, t}+\alpha_{3} * \Delta P O P_{i, t}+\alpha_{4} *\left(\Delta \text { CONTROLS }_{i, t}\right)+\alpha_{5} * \Delta O I L_{-} S_{i, t} \\
& +c_{1} * \Delta Y_{i, t-1}+c_{2} * C_{\text {CONFLICT }}+\tau_{t}+\epsilon_{i, t}
\end{aligned}
$$

\footnotetext{
${ }^{11}$ In all regressions, standard errors are robust to heteroscedasticity.
} 
Table 2 presents the long run estimates for these regressions. The coefficients of the baseline regression including investment, education, population and a dummy for minor conflicts (column Baseline) have the expected signs ${ }^{12}$, though education coefficient is not statistically significant likely due to the inclusion of country specific time trends which capture the slow and gradual impact of education on $\mathrm{GDP}^{13}$. The coefficient of the oil share (column Share) is negative and significant at the $1 \%$ level, pointing at the prevalence of the resource curse. The coefficient suggests that, ceteris paribus, a 10 percentage point increase in the oil share is associated with a 7\% lower GDP per capita level in the long run ${ }^{14}$. To ensure that this result is not driven by a relevant but omitted variable, several robustness checks are carried out:

- The oil share could have a negative impact mechanically when total exports fall (and thus oil share increases) which would have a negative impact on GDP. This is controlled for by introducing total exports (value, real terms, PPP-adjusted) in the regression (column Exports). The results still show a negative and significant impact of the oil share.

- Countries with high resource dependence could also be less open, with barriers to trade negatively affecting GDP. However controlling for trade openness (column Trade) delivers similar results.

- Another dimension of openness relates to capital controls: more resource dependent countries could impose more constraints on capital movements to limit impacts of oil price shocks. Using the Chin-Ito index of capital account openness (Chinn and Ito, 2006) still a significant negative impact of the oil share (column Capital) is found.

- Finally, resource dependent countries could potentially suffer from inadequate monetary policies leading to higher inflation. Controlling for inflation (column Inflation) produces qualitatively the same result.

In addition, a potentially nonlinear impact of the oil share using a quadratic term (Share2) is examined. Its negative coefficient (columns Nonlinear and Nonlin_Exp controlling for exports) would suggest that the negative impact of the oil dependence becomes stronger when the oil share increases, though the coefficient is not statistically significant and rather small.

\footnotetext{
12 The results of the baseline regression without computing the long run effect are presented in the Appendix. Notably, the convergence coefficient of the lagged dependent variable is equal to -0.08 which implies a faster convergence process than the -0.02 suggested by the "iron law of convergence" (Barro and Sala-i-Martin, 1992). This seems plausible as our sample mainly covers developing countries.

${ }^{13}$ As our dependent variable is the first difference of the logarithm of GDP and thus the growth rate, including country fixed effects accounts for country specific linear time trends.

14 The dependent variable is in logarithm contrary to oil share which is in percentage points. Thus, to get the percentage variation in the dependent variable, the oil share coefficient must be multiplied by 100 .
} 
Table 2. Impact of the oil exports share in total exports

\begin{tabular}{|c|c|c|c|c|c|c|c|c|}
\hline Variable & Baseline & Share & Exports & Trade & Capital & Inflation & Nonlinear & Nonlin_Exp \\
\hline \multirow[t]{2}{*}{ Investment } & $0.371^{* *}$ & $0.338^{* \star}$ & $0.199^{* *}$ & $0.285^{\star \star}$ & $0.317^{*}$ & $0.418^{*}$ & $0.340^{* *}$ & $0.186^{\star *}$ \\
\hline & {$[0.045]$} & {$[0.033]$} & {$[0.026]$} & [0.038] & [0.089] & {$[0.050]$} & [0.033] & {$[0.035]$} \\
\hline \multirow[t]{2}{*}{ Education } & 0.070 & 0.020 & 0.015 & 0.005 & 0.013 & 0.012 & 0.022 & 0.022 \\
\hline & {$[0.365]$} & {$[0.774]$} & {$[0.717]$} & {$[0.937]$} & {$[0.856]$} & {$[0.891]$} & {$[0.763]$} & {$[0.597]$} \\
\hline \multirow[t]{2}{*}{ Population } & $-0.955^{\star \star *}$ & $-0.994^{\star * *}$ & $-1.145^{\star \star *}$ & $-0.968^{\star * *}$ & $-0.909^{\star * *}$ & $-0.853^{\star *}$ & $-0.992^{\star * *}$ & $-1.156^{\star * \star}$ \\
\hline & [0.001] & {$[0.000]$} & {$[0.000]$} & {$[0.000]$} & {$[0.001]$} & {$[0.018]$} & {$[0.000]$} & {$[0.000]$} \\
\hline \multirow[t]{2}{*}{ Conflict } & -0.006 & 0.051 & -0.010 & 0.052 & 0.059 & 0.062 & 0.056 & 0.004 \\
\hline & {$[0.948]$} & [0.568] & {$[0.862]$} & [0.524] & {$[0.540]$} & [0.545] & {$[0.563]$} & [0.951] \\
\hline \multirow{2}{*}{ Share } & & $-0.007^{\star * *}$ & $-0.003^{\star *}$ & $-0.006^{\star * \star}$ & $-0.007^{\star \star *}$ & $-0.007^{\star * *}$ & $-0.007^{\star * \star}$ & $-0.003^{*}$ \\
\hline & & {$[0.003]$} & {$[0.029]$} & {$[0.003]$} & [0.003] & {$[0.009]$} & {$[0.003]$} & {$[0.052]$} \\
\hline \multirow[t]{2}{*}{ Exports } & & & $0.444^{* \star *}$ & & & & & $0.512^{\star \star \star}$ \\
\hline & & & {$[0.000]$} & & & & & {$[0.000]$} \\
\hline \multirow[t]{2}{*}{ Trade } & & & & 0.002 & & & & \\
\hline & & & & {$[0.118]$} & & & & \\
\hline \multirow[t]{2}{*}{ Capital } & & & & & 0.109 & & & \\
\hline & & & & & {$[0.404]$} & & & \\
\hline \multirow[t]{2}{*}{ Inflation } & & & & & & -0.006 & & \\
\hline & & & & & & [0.113] & & \\
\hline \multirow[t]{2}{*}{ Share2 } & & & & & & & -0.000 & $-0.000^{* *}$ \\
\hline & & & & & & & {$[0.766]$} & {$[0.043]$} \\
\hline \multirow[t]{2}{*}{ Constant } & $24.295^{\star \star \star}$ & $25.576^{\star \star \star}$ & $16.588^{\star \star *}$ & $25.056^{\star \star \star}$ & $24.317^{\star \star *}$ & $21.066^{\star \star *}$ & $25.263^{\star \star \star}$ & $14.852^{\star \star \star}$ \\
\hline & {$[0.000]$} & {$[0.000]$} & {$[0.000]$} & {$[0.000]$} & {$[0.000]$} & {$[0.000]$} & {$[0.000]$} & {$[0.000]$} \\
\hline $\mathrm{N}$ & 512 & 504 & 504 & 504 & 472 & 487 & 504 & 504 \\
\hline ar2 & 0.383 & 0.397 & 0.453 & 0.413 & 0.398 & 0.373 & 0.394 & 0.457 \\
\hline${ }^{*} p<0.10$ & ${ }^{* *} p<0.01$ & & & & & & & \\
\hline
\end{tabular}

Note: All the regressions include country fixed effects. P-values are displayed in brackets and based on robust standard errors. Example: a 10 percentage point increase in the share of oil exports (variable Share) is associated with a 7 percentage point lower long run GDP per capita (column Share).

Measuring the role of the quality of institutions for the resource curse proved difficult as few data prior to 1990 are available ${ }^{15}$. The ones finally used are 1) the political rights and civil liberty index from Freedom House, 2) "Polity IV" from the Center for Systemic Peace (index ranging from full autocracy to full democracy) and 3) a global measure of judicial independence (Linzer and Staton, 2015). All three take different aspects of institutional quality into account, which again allows checking the robustness of results. As noted in Acemoglu et al. (2015), a sufficient number of lags of the dependent variable is needed in estimating institutions' impact on GDP as a recession often precedes a change in institutions, making the relationship endogenous. Our specifications include two lags of the dependent variable and additional lags do not qualitatively change the results found below.

${ }^{15}$ See Ross (2015) for a global overview. 
Table 3. Impact of the oil share (controlling for institutions)

\begin{tabular}{|c|c|c|c|c|c|c|}
\hline Variable & Freedom & No_Freedom & Polity & No_Polity & Judiciary & No_Judiciary \\
\hline \multirow[t]{2}{*}{ Investment } & 0.245 & 0.228 & $0.299^{*}$ & $0.307^{*}$ & $0.319^{* *}$ & $0.322^{* \star}$ \\
\hline & [0.232] & [0.282] & {$[0.075]$} & {$[0.087]$} & {$[0.034]$} & [0.042] \\
\hline \multirow[t]{2}{*}{ Education } & -0.023 & -0.011 & 0.023 & 0.006 & 0.028 & 0.018 \\
\hline & [0.833] & [0.919] & {$[0.727]$} & {$[0.927]$} & {$[0.661]$} & [0.799] \\
\hline \multirow[t]{2}{*}{ Share } & -0.001 & -0.002 & $-0.007^{\star \star \star}$ & $-0.007^{\star \star \star}$ & $-0.007^{\star \star \star}$ & $-0.007^{\star * \star}$ \\
\hline & [0.845] & [0.646] & {$[0.001]$} & {$[0.001]$} & {$[0.002]$} & [0.002] \\
\hline \multirow[t]{2}{*}{ Population } & $-0.694^{*}$ & $-0.758^{* *}$ & $-0.952^{* * *}$ & $-0.987^{\star \star *}$ & $-1.078^{* * *}$ & $-0.994^{\star * *}$ \\
\hline & {$[0.066]$} & {$[0.048]$} & {$[0.000]$} & {$[0.000]$} & {$[0.000]$} & {$[0.000]$} \\
\hline \multirow[t]{2}{*}{ Conflict } & 0.103 & 0.101 & 0.082 & 0.050 & 0.094 & 0.050 \\
\hline & {$[0.427]$} & [0.472] & [0.343] & {$[0.555]$} & [0.305] & {$[0.569]$} \\
\hline \multirow[t]{2}{*}{ Freedom } & $-1.125^{*}$ & & & & & \\
\hline & {$[0.062]$} & & & & & \\
\hline \multirow[t]{2}{*}{ Polity } & & & $-0.019^{* *}$ & & & \\
\hline & & & {$[0.049]$} & & & \\
\hline \multirow[t]{2}{*}{ Judiciary } & & & & & $-0.955^{\star \star}$ & \\
\hline & & & & & {$[0.046]$} & \\
\hline \multirow[t]{2}{*}{ Constant } & $22.222^{* * *}$ & $19.925^{\star * *}$ & $24.790^{* * *}$ & $18.596^{* * *}$ & $27.132^{* * *}$ & $25.632^{* * *}$ \\
\hline & {$[0.000]$} & {$[0.000]$} & {$[0.000]$} & {$[0.000]$} & {$[0.000]$} & {$[0.000]$} \\
\hline $\mathrm{N}$ & 453 & 453 & 481 & 481 & 502 & 502 \\
\hline ar2 & 0.378 & 0.368 & 0.403 & 0.399 & 0.401 & 0.397 \\
\hline
\end{tabular}

Note: All the regressions include country fixed effects. P-values are displayed in brackets and based on robust standard errors.

First, more liberal, democratic or independent institutions as measured by variables Freedom, Polity and Judiciary respectively appear to have a negative impact on the long run GDP (Table 3) ${ }^{16}$. This result is in line with the previous findings by Barro (1996), Tavares and Wacziarg (2001) and Aisen and Veiga (2013). When quadratic terms are used for nonlinearities, as suggested by Figure 3, the relationship seems to change (Table 4): if institutional quality is low, an increase tends to reduce GDP, while if quality is already rather high, a further increase raises GDP, though the coefficients are not always statistically significant. These coefficients would imply that the impact of judicial independence, for instance, becomes positive at 0.73 , the indicator being bounded between 0 and $1{ }^{17}$. With certain controls such as exports and inflation (columns Freedom2_a, Polity2_a and Judiciary2_a), the quadratic term becomes statistically significant at $1 \%$ and $10 \%$ for Polity and judicial independence respectively.

\footnotetext{
${ }^{16}$ Higher values of variables Freedom, Polity and Judiciary translate more liberal, democratic and independent patterns respectively.

${ }^{17}$ Obtained by computing the derivative with respect to judicial independence in the estimated equation and solving for positive values.
} 
Table 4. Nonlinear impact of institutions

\begin{tabular}{|c|c|c|c|c|c|c|}
\hline Variable & Freedom2 & Polity2 & Judiciary2 & Freedom2_a & Polity2_a & Judiciary2_a \\
\hline \multirow[t]{2}{*}{ Investment } & 0.242 & $0.311^{*}$ & $0.308^{* *}$ & 0.161 & $0.202^{*}$ & $0.214^{\star *}$ \\
\hline & {$[0.235]$} & {$[0.061]$} & [0.043] & {$[0.160]$} & {$[0.060]$} & {$[0.037]$} \\
\hline \multirow[t]{2}{*}{ Education } & -0.006 & -0.014 & 0.009 & 0.004 & -0.012 & 0.010 \\
\hline & [0.955] & {$[0.841]$} & {$[0.900]$} & [0.942] & [0.798] & [0.842] \\
\hline \multirow[t]{2}{*}{ Share } & -0.001 & $-0.006^{* * *}$ & $-0.007^{\star \star *}$ & 0.000 & -0.001 & $-0.003^{* *}$ \\
\hline & {$[0.777]$} & {$[0.010]$} & {$[0.002]$} & [0.958] & [0.335] & {$[0.044]$} \\
\hline \multirow[t]{2}{*}{ Population } & $-0.725^{\star}$ & $-0.865^{\star * *}$ & $-1.150^{* \star *}$ & $-0.880^{* * *}$ & $-0.886^{\star * *}$ & $-1.132^{* * *}$ \\
\hline & {$[0.054]$} & {$[0.000]$} & {$[0.000]$} & [0.003] & {$[0.000]$} & {$[0.000]$} \\
\hline \multirow[t]{2}{*}{ Conflict } & 0.095 & 0.101 & 0.082 & 0.012 & 0.034 & 0.022 \\
\hline & {$[0.461]$} & {$[0.264]$} & [0.391] & [0.864] & [0.599] & [0.743] \\
\hline \multirow[t]{2}{*}{ Freedom } & -0.597 & & & -0.834 & & \\
\hline & [0.595] & & & [0.148] & & \\
\hline \multirow[t]{2}{*}{ Freedom2 } & -0.796 & & & 0.240 & & \\
\hline & [0.622] & & & [0.759] & & \\
\hline \multirow[t]{2}{*}{ Polity } & & -0.014 & & & -0.009 & \\
\hline & & [0.131] & & & [0.209] & \\
\hline \multirow[t]{2}{*}{ Polity2 } & & $0.004^{*}$ & & & $0.004^{* * *}$ & \\
\hline & & {$[0.073]$} & & & {$[0.009]$} & \\
\hline \multirow[t]{2}{*}{ Judiciary } & & & -1.709 & & & $-2.136^{* *}$ \\
\hline & & & [0.179] & & & {$[0.012]$} \\
\hline \multirow[t]{2}{*}{ Judiciary2 } & & & 1.166 & & & $2.300^{*}$ \\
\hline & & & [0.484] & & & {$[0.054]$} \\
\hline \multirow[t]{2}{*}{ Exports } & & & & $0.618^{\star * *}$ & $0.500^{* * *}$ & $0.510^{\star * \star}$ \\
\hline & & & & {$[0.000]$} & {$[0.000]$} & {$[0.000]$} \\
\hline \multirow[t]{2}{*}{ Inflation } & & & & $-0.005^{\star *}$ & $-0.004^{*}$ & $-0.004^{*}$ \\
\hline & & & & {$[0.046]$} & {$[0.076]$} & [0.068] \\
\hline \multirow[t]{2}{*}{ Constant } & $22.508^{\star \star *}$ & $23.380^{\star \star *}$ & $28.466^{* * *}$ & $7.933^{* \star}$ & $9.831^{* \star *}$ & $13.508^{\star \star *}$ \\
\hline & {$[0.000]$} & {$[0.000]$} & {$[0.000]$} & {$[0.027]$} & {$[0.001]$} & {$[0.000]$} \\
\hline$N$ & 453 & 481 & 502 & 438 & 464 & 485 \\
\hline ar2 & 0.380 & 0.409 & 0.401 & 0.418 & 0.468 & 0.459 \\
\hline
\end{tabular}

Note: All the regressions include country fixed effects. P-values are displayed in brackets and based on robust standard errors.

A possible explanation for a non-linear relation between institutions and growth is potential instability and uncertainty triggered by more liberal, democratic or independent institutions at their low levels. For example, in resource rich countries, an autocratic regime that would loosen its control over the judiciary could typically face attempts of powerful groups to influence or corrupt the judiciary to get more power. This, in turn, could destabilise decision-making processes, induce more unpredictability and scare investors ${ }^{18}$. Interestingly, there is no evidence of a damaging impact of resource dependence on institutions: the coefficient of the oil share is practically unchanged whether institutions are part of the regressors or not (Table 3).

${ }^{18}$ For instance, Tavares and Wacziarg (2001) find that democracy hinders growth by reducing the rate of physical capital accumulation and, less robustly, by increasing government consumption. Similarly, Aisen and Veiga (2013) show that political instability is particularly harmful through its adverse effects on total factor productivity growth and, in a lesser scale, by discouraging physical and human capital accumulation. 
Table 5. Impact of oil share conditional on institutions

\begin{tabular}{|c|c|c|c|c|c|c|c|}
\hline Variable & Share_Free & Share_Pol & Share_Jud & Share_Jud2 & Avrg_Free & Avrg_Pol & Avrg_Jud \\
\hline \multirow[t]{2}{*}{ Investment } & 0.244 & $0.351^{* *}$ & $0.340^{* *}$ & $0.327^{\star *}$ & 0.266 & $0.318^{*}$ & $0.355^{\star *}$ \\
\hline & [0.247] & {$[0.040]$} & [0.031] & [0.044] & [0.125] & {$[0.074]$} & {$[0.029]$} \\
\hline \multirow[t]{2}{*}{ Education } & -0.021 & 0.037 & 0.038 & 0.022 & 0.012 & 0.019 & 0.024 \\
\hline & [0.855] & [0.572] & {$[0.566]$} & [0.773] & [0.881] & {$[0.780]$} & {$[0.737]$} \\
\hline \multirow[t]{2}{*}{ Share } & -0.002 & $-0.006^{* * \star}$ & $-0.008^{\star \star *}$ & $-0.008^{* * *}$ & -0.004 & $-0.007^{* * *}$ & $-0.008^{\star \star *}$ \\
\hline & [0.531] & [0.003] & {$[0.001]$} & [0.001] & [0.159] & {$[0.002]$} & {$[0.001]$} \\
\hline \multirow[t]{2}{*}{ Population } & $-0.765^{*}$ & $-0.929^{* * *}$ & $-1.039^{* * *}$ & $-1.114^{* * *}$ & $-0.736^{\star \star *}$ & $-0.958^{* * *}$ & $-0.957^{* * *}$ \\
\hline & {$[0.055]$} & {$[0.000]$} & {$[0.000]$} & {$[0.000]$} & {$[0.008]$} & {$[0.000]$} & {$[0.000]$} \\
\hline \multirow[t]{2}{*}{ Conflict } & 0.112 & 0.107 & 0.087 & 0.077 & 0.041 & 0.051 & 0.045 \\
\hline & [0.413] & {$[0.236]$} & {$[0.366]$} & [0.471] & [0.687] & [0.567] & [0.630] \\
\hline \multirow[t]{2}{*}{ Freedom } & $-1.193^{*}$ & & & & & & \\
\hline & {$[0.059]$} & & & & & & \\
\hline \multirow{2}{*}{$\begin{array}{l}\text { Share } \mathrm{x} \\
\text { Freedom }\end{array}$} & $-0.021^{*}$ & & & & 0.007 & & \\
\hline & {$[0.084]$} & & & & [0.647] & & \\
\hline \multirow[t]{2}{*}{ Polity } & & $-0.017^{*}$ & & & & & \\
\hline & & {$[0.077]$} & & & & & \\
\hline \multirow{2}{*}{$\begin{array}{l}\text { Share x } \\
\text { Polity }\end{array}$} & & $-0.001^{* *}$ & & & & -0.001 & \\
\hline & & {$[0.016]$} & & & & [0.138] & \\
\hline \multirow[t]{2}{*}{ Judiciary } & & & -0.799 & -0.649 & & & \\
\hline & & & {$[0.100]$} & [0.295] & & & \\
\hline \multirow{2}{*}{$\begin{array}{l}\text { Share } x \\
\text { Judiciary }\end{array}$} & & & -0.012 & -0.012 & & & $-0.016^{*}$ \\
\hline & & & {$[0.110]$} & {$[0.140]$} & & & {$[0.096]$} \\
\hline \multirow[t]{2}{*}{ Share2 } & & & & -0.000 & & & \\
\hline & & & & {$[0.609]$} & & & \\
\hline \multirow[t]{2}{*}{ Judiciary2 } & & & & 0.624 & & & \\
\hline & & & & {$[0.724]$} & & & \\
\hline \multirow[t]{2}{*}{ Constant } & $22.914^{\star * *}$ & $24.211^{\star \star *}$ & $25.759^{* * *}$ & $27.009^{\star * *}$ & $21.678^{\star * *}$ & $24.854^{\star * *}$ & $24.681^{* * *}$ \\
\hline & {$[0.000]$} & {$[0.000]$} & {$[0.000]$} & {$[0.000]$} & {$[0.000]$} & {$[0.000]$} & {$[0.000]$} \\
\hline$N$ & 453 & 481 & 502 & 502 & 473 & 481 & 504 \\
\hline ar2 & 0.383 & 0.413 & 0.405 & 0.403 & 0.376 & 0.401 & 0.401 \\
\hline
\end{tabular}

Note: All the regressions include country fixed effects. P-values are displayed in brackets and based on robust standard errors.

Finally, Table 5 presents the results of interaction of the oil share and institutions (columns Share_Free, Share_Pol and Share_Jud) to assess whether the impact of resource dependence relies on institutional quality. All three measures point to a stronger negative impact of the oil share when the institutional quality increases, though only a part of the results is significant. Furthermore, the inclusion of a quadratic term in column Share_Jud2 $2^{19}$ does not affect the interaction term coefficient which excludes the fact that the interaction term coefficient could be driven by omitted nonlinearities of the terms that are interacted or country slope heterogeneity.

${ }^{19}$ As suggested in Balli and Sorensen (2013), the regression of column Share_Jud2 also includes the quadratic terms of the variables that are interacted to ensure robustness to heterogeneity in coefficients across countries, nonlinearities and avoid false significance of the interaction term. 
Overall the results on institutional quality should be taken with caution as the sample is dominated by countries with weak institutions. To measure the impact of institutions appropriately requires a sample with a larger share of high quality institutions countries and an alternative to the fixed effect estimators, to take into account the between countries variability in institutions. To partially bypass the last problem we also interact the oil share with an average instead of yearly value of institutional variable for every country, to preserve between country variability in institutions, though only for country averages over years. Results as portrayed in columns Avrg_Pol and Avrg_Jud do however not change qualitatively, and outlier-robust regressions confirm these findings too.

Finally, a possible explanation as to why higher oil dependence appears to have a more harmful effect in countries with better institutions could be linked to a variable that is positively affected by institutions and negatively affected by the oil dependence, such as the degree of competition in an economy ${ }^{20}$. If competition has a positive effect on GDP, the interaction term could capture the negative effect of oil dependence on competition which would explain the negative coefficient of the interaction term.

\section{Oil price shocks}

The impact of oil price fluctuations on short and long-term growth is analysed estimating the following equation:

$$
\begin{array}{rl}
\Delta Y_{i, t}=\alpha_{i}+\alpha_{0} & *\left[Y_{i, t-1}+b_{1} * \operatorname{INVEST}_{i, t-1}+b_{2} * \operatorname{EDUM}_{i, t-1}+b_{3} * \operatorname{POP}_{i, t-1}+b_{4}\right. \\
& \left.*\left(\text { CONTROLS }_{i, t-1}\right)+b_{5} * O \mathrm{OI}_{t-1}\right]+\alpha_{1} * \Delta I N V E S T_{i, t}+\alpha_{2} \\
& * \Delta E D U M_{i, t}+\alpha_{3} * \Delta P O P_{i, t}+\alpha_{4} *\left(\Delta \operatorname{CONTROLS}_{i, t}\right)+\alpha_{5} * \Delta O I L_{t} \\
& +c_{1} * \Delta Y_{i, t-1}+c_{2} * \operatorname{CONFLICT}_{i, t}+c_{3} * \operatorname{CRISIS}_{t}+\epsilon_{i, t}
\end{array}
$$

where $O I L$ is the logarithm of the real average dollar price of the three benchmarks of oil (WTI, Brent and Dubai). We use internationally set dollar oil prices to preserve exogeneity of the oil price variable. This variable is common across countries and as a consequence time fixed effects cannot be used. Instead a dummy CRISIS for the year 2009 is introduced. As the impact of an oil price shock will typically be influenced by the fiscal response of governments, variables such as government consumption will be added, even if the latter is subject to the same shocks as GDP. In any case, we systematically present both regressions, with and without government consumption ${ }^{21}$.

Table 6 displays the results for the oil price fluctuation regressions. In the baseline an oil price increase has a positive and significant effect on GDP in the short run and no significant effect in the long run ${ }^{22}$ (column OIL), suggesting that a $10 \%$ increase in the oil price is associated with a contemporary $0.27 \%$ rise in GDP per capita. Controlling for government consumption (column Oil_Gov) yields a stronger result of a $0.38 \%$ increase. As government consumption has a positive impact on GDP, this result - a greater oil price

\footnotetext{
${ }^{20}$ Taking into account the commonly monopolistic nature of the oil sector, it seems plausible to assume that the larger the oil sector, the weaker the overall degree of competition in the economy.

${ }^{21}$ As for GDP, the government consumption is expressed in real terms, PPP adjusted.

22 The fact that the short run positive effect of an oil price increase disappears in the long run may indirectly support the Dutch disease hypothesis.
} 
coefficient holding government consumption constant - points towards a kind of countercyclical fiscal policy: when the oil price rises, governments reduce spending ${ }^{23}$. Countercyclical fiscal policy could be explained by the prevalence of sovereign wealth or stabilisation funds in many countries to help counter oil price fluctuations (Table 16 in the Appendix). We control that the oil price impact is not driven by changes in capital movement restrictions by introducing capital account openness index which produces qualitatively same results.

Table 6. Impact of the oil price fluctuations for growth

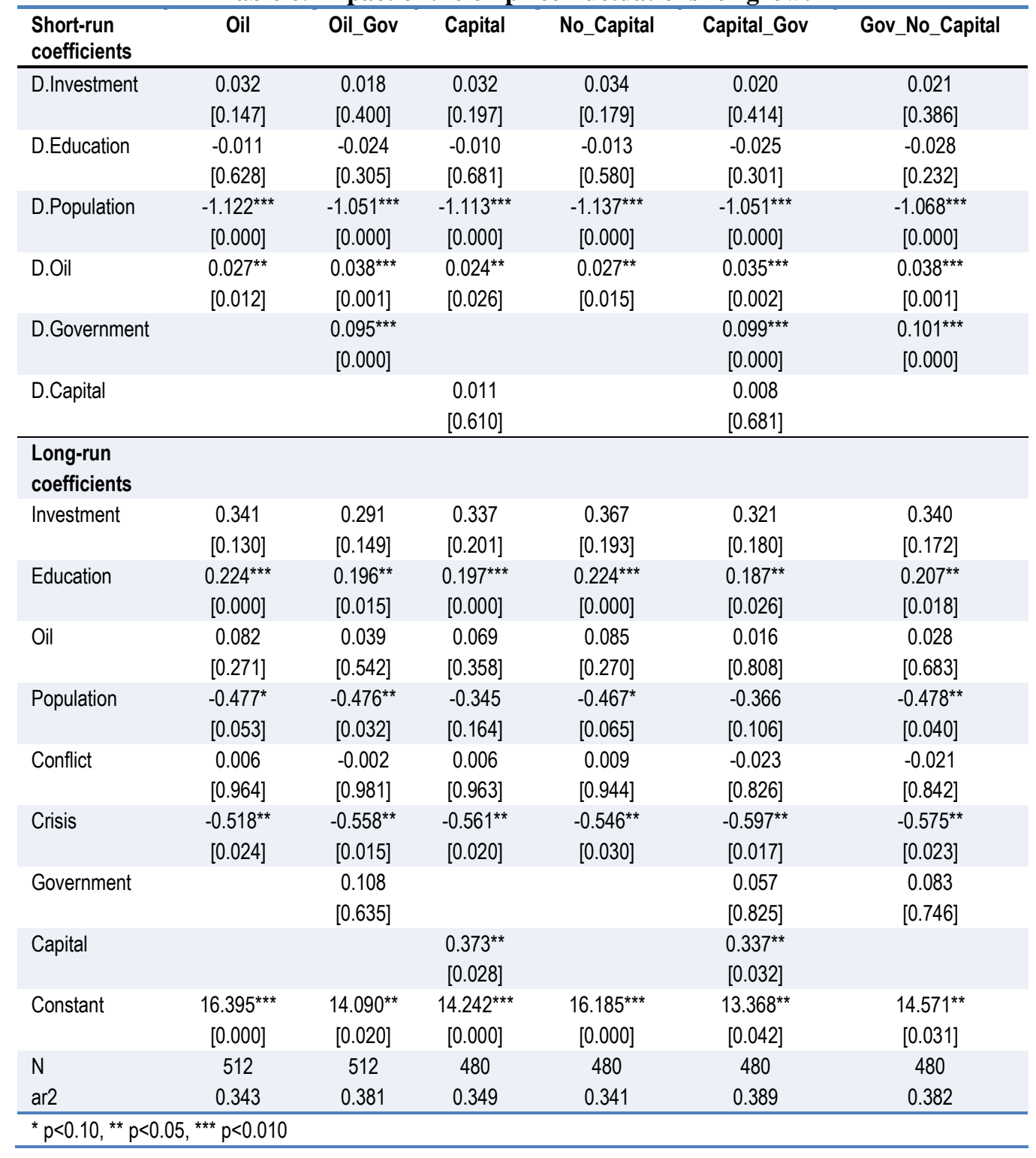

Note: P-values are displayed in brackets and based on robust standard errors.

${ }^{23}$ This result complements similar findings on fiscal policy by Egert (2010) for OECD countries. 
Exchange rates and inflation may play a role in the transmission of oil price shocks to economic activity. One of the potential channels in the case of an oil price fall is the contraction of real disposable income as the currency tends to depreciate and inflation to accelerate. We test this hypothesis by controlling for different exchange rates ${ }^{24}$ (Table 7 , columns Forex, NEER, REER for nominal, nominal effective and real effective exchange rates respectively). Constraining the exchange rate to remain constant does not have great impact on the oil price coefficient. In fact, countries may experience large currency depreciations but with different consequences for inflation depending whether the depreciation is smooth or abrupt (Dabrowski, 2015). Therefore, we control directly for inflation (Table 8, columns Infl and Infl_Gov). Here again, the oil price coefficient hardly changes when we hold inflation constant (both with and without government consumption), clearly too little to consider inflation as an important channel.

Table 7. Impact of the oil price (controlling for exchange rates)

\begin{tabular}{|c|c|c|c|c|c|c|c|c|c|c|}
\hline $\begin{array}{l}\text { Short-run } \\
\text { coefficients }\end{array}$ & Oil & Oil_Gov & Forex & $\begin{array}{l}\text { No_ } \\
\text { Forex }\end{array}$ & $\begin{array}{l}\text { Forex } \\
\text { Gov }\end{array}$ & $\begin{array}{c}\text { Gov_No } \\
\text { Forex }\end{array}$ & NEER & $\begin{array}{c}\text { NEER } \\
\text { Gov }\end{array}$ & REER & $\begin{array}{l}\text { REER } \\
\text { Gov }\end{array}$ \\
\hline \multirow[t]{2}{*}{ D.Investment } & 0.032 & 0.018 & 0.029 & 0.031 & 0.015 & 0.017 & 0.031 & 0.017 & 0.030 & 0.018 \\
\hline & {$[0.147]$} & {$[0.400]$} & {$[0.197]$} & {$[0.171]$} & {$[0.476]$} & [0.439] & [0.159] & {$[0.413]$} & {$[0.164]$} & {$[0.404]$} \\
\hline \multirow[t]{2}{*}{ D.Education } & -0.011 & -0.024 & -0.016 & -0.015 & -0.028 & -0.028 & -0.011 & -0.023 & -0.014 & -0.024 \\
\hline & {$[0.628]$} & {$[0.305]$} & [0.492] & {$[0.518]$} & {$[0.215]$} & {$[0.231]$} & {$[0.657]$} & {$[0.318]$} & {$[0.559]$} & {$[0.296]$} \\
\hline \multirow[t]{2}{*}{ D.Population } & $-1.122^{* * *}$ & $-1.051^{\text {*** }}$ & $-1.106^{\star \star *}$ & $-1.095^{\star * *}$ & $-1.052^{\star * *}$ & $-1.035^{\star \star *}$ & $-1.110^{* * *}$ & $-1.040^{* * *}$ & $-1.103^{\star * *}$ & $-1.039^{* * *}$ \\
\hline & {$[0.000]$} & {$[0.000]$} & {$[0.000]$} & {$[0.000]$} & {$[0.000]$} & {$[0.000]$} & {$[0.000]$} & {$[0.000]$} & {$[0.000]$} & {$[0.000]$} \\
\hline \multirow[t]{2}{*}{ D.Oil } & $0.027^{\star *}$ & $0.038^{* * *}$ & $0.028^{\star \star}$ & $0.029^{\star * *}$ & $0.038^{* * *}$ & $0.040^{* * *}$ & $0.026^{* *}$ & $0.038^{* * *}$ & $0.024^{\star *}$ & $0.036^{\star * *}$ \\
\hline & {$[0.012]$} & {$[0.001]$} & {$[0.015]$} & {$[0.009]$} & {$[0.001]$} & {$[0.001]$} & {$[0.015]$} & {$[0.001]$} & {$[0.023]$} & {$[0.001]$} \\
\hline \multirow[t]{2}{*}{ D.Government } & & $0.095^{\star * *}$ & & & $0.091^{* * *}$ & $0.095^{\star * *}$ & & $0.095^{\star * *}$ & & $0.092^{* * *}$ \\
\hline & & {$[0.000]$} & & & [0.001] & {$[0.000]$} & & {$[0.000]$} & & {$[0.000]$} \\
\hline \multirow[t]{2}{*}{ D.Forex } & & & $0.078^{* *}$ & & $0.069^{\star \star}$ & & & & & \\
\hline & & & {$[0.015]$} & & {$[0.026]$} & & & & & \\
\hline \multirow[t]{2}{*}{ D.NEER } & & & & & & & 0.001 & -0.001 & & \\
\hline & & & & & & & {$[0.860]$} & {$[0.841]$} & & \\
\hline \multirow[t]{2}{*}{ D.REER } & & & & & & & & & $0.011^{*}$ & 0.005 \\
\hline & & & & & & & & & {$[0.090]$} & {$[0.355]$} \\
\hline$N$ & 512 & 512 & 481 & 481 & 481 & 481 & 512 & 512 & 512 & 512 \\
\hline ar2 & 0.343 & 0.381 & 0.354 & 0.347 & 0.390 & 0.385 & 0.341 & 0.379 & 0.346 & 0.380 \\
\hline
\end{tabular}

Note: All the regressions include a crisis dummy. P-values are displayed in brackets and based on robust standard errors.

${ }^{24}$ The exchange rates were normalized by dividing them by their standard deviation. 
Table 8. Impact of the oil price (controlling for inflation)

\begin{tabular}{|c|c|c|c|c|}
\hline Short-run coefficients & Infl & No_Infl & Infl_Gov & Gov_No_Infl \\
\hline \multirow[t]{2}{*}{ D.Investment } & 0.032 & 0.033 & 0.019 & 0.017 \\
\hline & {$[0.127]$} & {$[0.140]$} & {$[0.371]$} & {$[0.421]$} \\
\hline \multirow[t]{2}{*}{ D.Education } & -0.027 & -0.024 & -0.036 & -0.036 \\
\hline & {$[0.259]$} & {$[0.325]$} & {$[0.137]$} & {$[0.147]$} \\
\hline \multirow[t]{2}{*}{ D.Population } & $-1.271^{\star * *}$ & $-1.394^{\star * *}$ & $-1.241^{\star * *}$ & $-1.298^{\star \star *}$ \\
\hline & {$[0.005]$} & {$[0.002]$} & {$[0.004]$} & {$[0.003]$} \\
\hline \multirow[t]{2}{*}{ D.Oil } & $0.022^{* *}$ & $0.023^{\star *}$ & $0.031^{* * *}$ & $0.033^{* * *}$ \\
\hline & {$[0.030]$} & {$[0.027]$} & {$[0.003]$} & {$[0.002]$} \\
\hline \multirow[t]{2}{*}{ D.Government } & & & $0.086^{\star * \star}$ & $0.099^{\star \star *}$ \\
\hline & & & {$[0.001]$} & {$[0.000]$} \\
\hline \multirow[t]{2}{*}{ D.Inflation } & $-0.001^{* *}$ & & $-0.001^{*}$ & \\
\hline & {$[0.018]$} & & {$[0.090]$} & \\
\hline $\mathrm{N}$ & 495 & 495 & 495 & 495 \\
\hline ar2 & 0.320 & 0.301 & 0.349 & 0.343 \\
\hline
\end{tabular}

Note: All the regressions include a crisis dummy. P-values are displayed in brackets and based on robust standard errors.

The impact of the oil price shock could be substantially different subject to oil dependence. This is tested by interacting the oil price with the oil share in the following equation ${ }^{25}$ :

$$
\begin{array}{rl}
\Delta Y_{i, t}=\alpha_{i}+\alpha_{0} & *\left[Y_{i, t-1}+b_{1} * I N V E S T_{i, t-1}+b_{2} * E_{\text {EDUM }}+t-1+b_{3} * P O P_{i, t-1}+b_{4}\right. \\
& *\left(\text { CONTROLS }_{i, t-1}\right)+b_{5} * O I L_{t-1}+b_{6} * O I L_{-} S_{i, t-1}+b_{7} \\
& \left.*\left(O I L_{t-1} * O I S_{-} S_{i, t-1}\right)\right]+\alpha_{1} * \Delta I N V E S T_{i, t}+\alpha_{2} * \Delta E D U M_{i, t}+\alpha_{3} \\
& * \Delta P O P_{i, t}+\alpha_{4} *\left(\Delta C O N T R O L S_{i, t}\right)+\alpha_{5} * O I L_{t}+\alpha_{6} * O I L_{-} S_{i, t}+\alpha_{7} \\
& *\left(O I L_{t} * O I L_{-} S_{i, t}\right)+c_{1} * \Delta Y_{i, t-1}+c_{2} * \text { CONFLICT }_{i, t}+c_{3} * \text { CRISIS }_{t} \\
& +\epsilon_{i, t}
\end{array}
$$

Table 9 presents the results. We explicitly compute the oil price impact at the minimum, mean and maximum values of oil share. The impact of an oil price shock first decreases with the oil share, but once government consumption is controlled for the impact becomes increasing as expected. This result also suggests that the more countries rely on oil exports, the more they use fiscal policies to smooth oil price fluctuations. We check again that our results are not driven by changes in capital account openness and assess potential exchange rate and inflation channels. The results are similar to those found previously.

${ }^{25}$ Variables $O I L, O I L \_S$ and their interaction are inserted in levels (in $t$ ) instead of differences to allow computing marginal effect of $O I L$ at different level of $O I L \_S$. It can be shown that these two writings are equivalent. 
Table 9. Impact of the oil price conditional on oil share

\begin{tabular}{|c|c|c|c|c|c|c|}
\hline $\begin{array}{l}\text { Short-run } \\
\text { coefficients }\end{array}$ & Oil & Oil_Gov & Infl & No_Infl & Infl_Gov & Gov_No_Infl \\
\hline \multirow[t]{2}{*}{ D.Investment } & 0.029 & 0.018 & 0.030 & 0.030 & 0.019 & 0.018 \\
\hline & [0.173] & {$[0.397]$} & {$[0.138]$} & {$[0.153]$} & {$[0.336]$} & [0.394] \\
\hline \multirow[t]{2}{*}{ D.Education } & -0.023 & -0.037 & $-0.040^{*}$ & -0.036 & $-0.050^{\star \star}$ & $-0.050^{*}$ \\
\hline & [0.323] & {$[0.121]$} & {$[0.090]$} & {$[0.139]$} & {$[0.044]$} & {$[0.050]$} \\
\hline \multirow[t]{2}{*}{ D.Population } & $-1.149^{\star * *}$ & $-0.976^{\star \star *}$ & $-1.362^{\star * \star}$ & $-1.506^{\star * *}$ & $-1.198^{* * *}$ & $-1.256^{\star \star *}$ \\
\hline & {$[0.000]$} & {$[0.000]$} & {$[0.001]$} & {$[0.000]$} & [0.003] & {$[0.002]$} \\
\hline \multirow[t]{2}{*}{ D.Government } & & $0.103^{\star * *}$ & & & $0.090^{* * *}$ & $0.106^{* \star *}$ \\
\hline & & {$[0.000]$} & & & {$[0.001]$} & {$[0.000]$} \\
\hline \multirow[t]{2}{*}{ D.Inflation } & & & $-0.001^{* *}$ & & $-0.001^{*}$ & \\
\hline & & & {$[0.011]$} & & {$[0.062]$} & \\
\hline \multirow{2}{*}{ D.Oil_min } & $0.036^{\star * *}$ & $0.035^{\star \star *}$ & $0.029^{\star *}$ & $0.034^{* *}$ & $0.030^{\star \star}$ & $0.033^{\star \star \star}$ \\
\hline & {$[0.009]$} & {$[0.005]$} & {$[0.018]$} & {$[0.014]$} & {$[0.013]$} & {$[0.009]$} \\
\hline \multirow[t]{2}{*}{ D.Oil_mean } & $0.034^{* \star *}$ & $0.048^{\star * *}$ & $0.026^{\star *}$ & $0.028^{* *}$ & $0.038^{* * *}$ & $0.042^{* * *}$ \\
\hline & {$[0.003]$} & {$[0.000]$} & {$[0.020]$} & {$[0.019]$} & {$[0.001]$} & {$[0.001]$} \\
\hline \multirow[t]{2}{*}{ D.Oil_max } & 0.031 & $0.066^{\star * *}$ & 0.021 & 0.019 & $0.051^{* *}$ & $0.055^{\star \star}$ \\
\hline & {$[0.145]$} & {$[0.003]$} & {$[0.300]$} & {$[0.381]$} & {$[0.019]$} & {$[0.014]$} \\
\hline $\mathrm{N}$ & 504 & 504 & 487 & 487 & 487 & 487 \\
\hline ar2 & 0.352 & 0.391 & 0.331 & 0.307 & 0.359 & 0.351 \\
\hline
\end{tabular}

Note: All the regressions include a crisis dummy. P-values are displayed in brackets and based on robust standard errors.

We finally look at the asymmetry of the oil price impact by estimating the following equation:

$$
\begin{array}{rl}
\Delta Y_{i, t}=\alpha_{i}+\alpha_{0} & *\left[Y_{i, t-1}+b_{1} * \operatorname{INVEST}_{i, t-1}+b_{2} * \operatorname{EDUM}_{i, t-1}+b_{3} * \text { POP }_{i, t-1}+b_{4}\right. \\
& \left.*\left(\text { CONTROLS }_{i, t-1}\right)+b_{5} * \text { OIL }_{t-1}\right]+\alpha_{1} * \Delta \operatorname{INVEST}_{i, t}+\alpha_{2} \\
& * \Delta \text { EDUM }_{i, t}+\alpha_{3} * \Delta \text { POP }_{i, t}+\alpha_{4} *\left(\Delta \text { CONTROLS }_{i, t}\right)+\alpha_{5} * \operatorname{DOILP}_{t} \\
& +\alpha_{6} * \operatorname{DOILN}_{t}+c_{1} * \Delta Y_{i, t-1}+c_{2} * \operatorname{CONFLICT}_{i, t}+c_{3} * \operatorname{CRISIS}_{t}+\epsilon_{i, t}
\end{array}
$$

Following Mork et al. (1994) oil price changes are split into a positive (OILP) and negative (OILN) oil price change. As shown in Table 10, the impact is in fact asymmetric: significantly positive in case of a positive shock and not significant in case of a negative shock. It appears that on average, oil exporting countries are able to gain from oil price increases while neutralising the negative effects of oil price slumps. One could suspect an endogeneity problem: a major oil exporting country lowering the oil price by increasing its production could explain the insignificant coefficient of negative oil price shocks. We control for country oil production by introducing the logarithm of oil production (variable Production, columns Prod, Prod_Gov). The coefficients of OILP and OILN and their significance are qualitatively unchanged, however. 
Table 10. Asymmetry of the oil price shock

\begin{tabular}{|c|c|c|c|c|c|c|}
\hline Short-run coefficients & Prod & No_Prod & Prod_Gov & Gov_No_Prod & Forex & No_Forex \\
\hline \multirow[t]{2}{*}{ D.Investment } & $0.053^{* \star}$ & 0.045 & 0.036 & 0.026 & 0.029 & 0.031 \\
\hline & {$[0.048]$} & {$[0.108]$} & {$[0.202]$} & {$[0.360]$} & [0.198] & {$[0.167]$} \\
\hline \multirow[t]{2}{*}{ D.Education } & 0.002 & -0.010 & -0.012 & -0.024 & -0.016 & -0.015 \\
\hline & {$[0.940]$} & {$[0.658]$} & {$[0.601]$} & {$[0.305]$} & {$[0.497]$} & {$[0.536]$} \\
\hline \multirow[t]{2}{*}{ D.Population } & $-1.086^{* * *}$ & $-1.114^{* * *}$ & $-1.033^{* * *}$ & $-0.998^{\star * *}$ & $-1.108^{* * *}$ & $-1.101^{* * *}$ \\
\hline & {$[0.000]$} & {$[0.000]$} & {$[0.000]$} & {$[0.000]$} & {$[0.000]$} & {$[0.000]$} \\
\hline \multirow[t]{2}{*}{ D.Oilp } & $0.029^{* *}$ & $0.026^{*}$ & $0.045^{* \star *}$ & $0.047^{\star \star \star}$ & $0.029^{* *}$ & $0.034^{* *}$ \\
\hline & {$[0.040]$} & {$[0.088]$} & {$[0.002]$} & {$[0.003]$} & {$[0.046]$} & {$[0.020]$} \\
\hline \multirow[t]{2}{*}{ D.Oiln } & 0.019 & 0.010 & 0.022 & 0.015 & 0.026 & 0.026 \\
\hline & {$[0.231]$} & {$[0.539]$} & {$[0.144]$} & {$[0.343]$} & {$[0.111]$} & {$[0.128]$} \\
\hline \multirow[t]{2}{*}{ D.Government } & & & $0.103^{\star \star *}$ & $0.128^{\star \star \star}$ & & \\
\hline & & & {$[0.001]$} & {$[0.000]$} & & \\
\hline \multirow[t]{2}{*}{ D.Production } & $0.087^{\star * *}$ & & $0.078^{\star \star \star}$ & & & \\
\hline & {$[0.001]$} & & {$[0.002]$} & & & \\
\hline \multirow[t]{2}{*}{ D.Forex } & & & & & $0.078^{\star *}$ & \\
\hline & & & & & {$[0.015]$} & \\
\hline $\mathrm{N}$ & 405 & 405 & 405 & 405 & 481 & 481 \\
\hline ar2 & 0.430 & 0.351 & 0.463 & 0.401 & 0.353 & 0.346 \\
\hline
\end{tabular}

Note: All the regressions include a crisis dummy. P-values are displayed in brackets and based on robust standard errors.

\section{The role of the exchange rate regime}

More than half of the country-observations in the sample have a form of fixed exchange rate (Table 11). A vast literature discusses advantages and drawbacks of fixed and flexible exchange rate regimes, without reaching a consensus ${ }^{26}$. On the one hand, rapid adjustment to external shocks which avoids balance of payment crises and helps keep monetary autonomy are often seen as an advantage of a flexible exchange rate regime. On the other hand, high exchange rate volatility and inflation pass-through are the drawbacks, particularly for oil dependent countries. In developing countries, a fixed exchange rate regime may have the advantage of inflation anchoring and lower transaction costs of foreign trade as exchange rate volatility is absent. But it may also induce balance of payment crises and requires more active fiscal policies to counter external shocks.

Table 11. Prevalence of exchange rate regimes

\begin{tabular}{lccc}
\hline Regime & N obs & \% of total & \% cumulative \\
\hline Fixed & 257 & 52.0 & 52.0 \\
Crawling & 65 & 13.2 & 65.2 \\
Managed & 96 & 19.4 & 84.6 \\
Flexible & 76 & 15.4 & 100.0 \\
\hline
\end{tabular}

Source: Authors calculations based on Ghosh et al. (2015).

We analyse the long run impact of exchange rate regimes using our baseline equation augmented with exchange rate regime dummies for crawling, managed and flexible

${ }^{26}$ See Levy-Yeyati and Sturzenegger (2001), Reinhardt and Rogoff (2004), Ghosh and Ostry (2009), Obstfeld et al. (2017). 
regimes (variables Crawling, Managed and Flexible respectively) using the classification based on Ghosh et al. (2015). Table 12 provides a quick overview of the distribution of exchange rate regimes by country (values 1,2, 3, 4 for fixed, crawling, managed and flexible regimes respectively). Some countries - where the mean and standard deviation equal 1 and 0 respectively - effectively maintained a fixed exchange rate regime throughout the entire period.

Table 12. Exchange rate regime distribution by country

\begin{tabular}{|c|c|c|c|}
\hline Country & Mean & Std. Dev. & N obs \\
\hline Algeria & 2.5 & 0.5 & 24 \\
\hline Bahrain & 1.0 & 0.0 & 22 \\
\hline Brunei Darussalam & 1.0 & 0.0 & 22 \\
\hline Cameroon & 1.0 & 0.0 & 15 \\
\hline Canada & 3.6 & 0.5 & 30 \\
\hline Colombia & 2.5 & 0.7 & 19 \\
\hline Congo, Dem. Rep. & 3.8 & 0.4 & 6 \\
\hline Congo & 1.0 & 0.0 & 27 \\
\hline Ecuador & 1.5 & 0.7 & 30 \\
\hline Egypt & 1.8 & 1.0 & 26 \\
\hline Gabon & 1.0 & 0.0 & 25 \\
\hline Indonesia & 2.5 & 0.8 & 22 \\
\hline Kazakhstan & 2.6 & 0.6 & 14 \\
\hline Kuwait & 1.0 & 0.0 & 21 \\
\hline Libya & 1.0 & 0.0 & 7 \\
\hline Malaysia & 2.2 & 0.9 & 30 \\
\hline Mexico & 3.7 & 0.6 & 19 \\
\hline Norway & 2.7 & 1.3 & 30 \\
\hline Papua New Guinea & 3.5 & 1.1 & 13 \\
\hline Russia & 3.0 & 0.0 & 11 \\
\hline Saudi Arabia & 1.1 & 0.3 & 30 \\
\hline Trinidad and Tobago & 1.4 & 0.9 & 30 \\
\hline United Arab Emirates & 1.0 & 0.0 & 10 \\
\hline Yemen & 3.5 & 0.9 & 11 \\
\hline
\end{tabular}

Source: Authors calculations based on Ghosh et al. (2015).

Importantly, the exchange rate regime could endogenously change in the wake of an oil price shock when it becomes unsustainable. The depletion of foreign reserves to maintain the peg could lead to a balance of payment crisis and force abandoning the peg. In this regard, it is necessary to control for oil price shocks but also other types of global shocks. For this reason, we prefer to include year fixed effects instead of the oil price, which should still capture oil price shocks but also other shocks.

Results suggest that more flexible exchange rate regimes seem to have a negative impact on long run GDP for oil-exporting countries (Table 13), although some coefficients are not significant. Results are robust to additional controls for government consumption, level of financial development, inflation, trade openness and oil dependence (columns Regime_Gov, Finance_Gov, Infl_Gov, Trade_Gov and Share_Gov respectively). 
Table 13. Impact of exchange rate regime

\begin{tabular}{|c|c|c|c|c|c|c|}
\hline $\begin{array}{l}\text { Long-run } \\
\text { coefficients }\end{array}$ & Regime & Regime_Gov & Finance_Gov & Infl_Gov & Trade_Gov & Share_Gov \\
\hline \multirow[t]{2}{*}{ Investment } & $0.343^{* \star}$ & $0.300^{*}$ & $0.327^{*}$ & $0.283^{*}$ & $0.242^{*}$ & $0.220^{*}$ \\
\hline & {$[0.043]$} & {$[0.059]$} & {$[0.050]$} & {$[0.087]$} & {$[0.082]$} & {$[0.057]$} \\
\hline \multirow[t]{2}{*}{ Education } & 0.069 & 0.047 & 0.051 & 0.017 & 0.030 & -0.012 \\
\hline & {$[0.377]$} & [0.571] & [0.511] & {$[0.854]$} & {$[0.700]$} & {$[0.837]$} \\
\hline \multirow{2}{*}{ Population } & $-1.214^{* * *}$ & $-1.233^{\star * *}$ & $-1.204^{* * *}$ & $-1.102^{* \star *}$ & $-1.183^{* * *}$ & $-1.135^{* * *}$ \\
\hline & {$[0.000]$} & {$[0.000]$} & {$[0.000]$} & {$[0.003]$} & {$[0.000]$} & {$[0.000]$} \\
\hline \multirow{2}{*}{ Crawling } & -0.164 & $-0.171^{*}$ & $-0.175^{\star}$ & -0.149 & -0.143 & -0.132 \\
\hline & {$[0.146]$} & {$[0.091]$} & {$[0.057]$} & {$[0.153]$} & {$[0.110]$} & {$[0.103]$} \\
\hline \multirow[t]{2}{*}{ Managed } & $-0.127^{*}$ & $-0.108^{*}$ & -0.105 & -0.100 & -0.094 & -0.056 \\
\hline & {$[0.079]$} & {$[0.098]$} & {$[0.115]$} & {$[0.140]$} & {$[0.123]$} & {$[0.315]$} \\
\hline \multirow[t]{2}{*}{ Flexible } & $-0.413^{\star * *}$ & $-0.340^{\star * *}$ & $-0.292^{\star * \star}$ & $-0.328^{\star *}$ & $-0.300^{\star \star *}$ & $-0.243^{* *}$ \\
\hline & {$[0.003]$} & {$[0.005]$} & {$[0.010]$} & {$[0.012]$} & {$[0.006]$} & {$[0.014]$} \\
\hline \multirow[t]{2}{*}{ Conflict } & -0.046 & -0.059 & -0.060 & -0.053 & -0.044 & 0.008 \\
\hline & {$[0.589]$} & {$[0.421]$} & {$[0.371]$} & {$[0.488]$} & {$[0.513]$} & {$[0.889]$} \\
\hline \multirow[t]{2}{*}{ Government } & & -0.008 & 0.059 & 0.089 & 0.036 & 0.179 \\
\hline & & {$[0.965]$} & {$[0.720]$} & {$[0.622]$} & {$[0.818]$} & {$[0.147]$} \\
\hline \multirow[t]{2}{*}{ Finance } & & & -0.028 & & & \\
\hline & & & {$[0.385]$} & & & \\
\hline \multirow[t]{2}{*}{ Inflation } & & & & 0.001 & & \\
\hline & & & & {$[0.762]$} & & \\
\hline \multirow[t]{2}{*}{ Trade } & & & & & $0.002^{*}$ & \\
\hline & & & & & {$[0.092]$} & \\
\hline \multirow[t]{2}{*}{ Share } & & & & & & $-0.006^{\star * *}$ \\
\hline & & & & & & {$[0.002]$} \\
\hline \multirow[t]{2}{*}{ Constant } & $27.992^{* * *}$ & $28.555^{\star * *}$ & $26.386^{\star * *}$ & $22.035^{\star \star *}$ & $26.727^{\star \star *}$ & $23.513^{* * *}$ \\
\hline & {$[0.000]$} & {$[0.000]$} & {$[0.000]$} & {$[0.001]$} & {$[0.000]$} & {$[0.000]$} \\
\hline $\mathrm{N}$ & 494 & 494 & 472 & 478 & 494 & 486 \\
\hline ar2 & 0.393 & 0.436 & 0.450 & 0.412 & 0.443 & 0.447 \\
\hline${ }^{*} p<0.10$ & $5,{ }^{* * *} p<$ & & & & & \\
\hline
\end{tabular}

Note: All the regressions include country fixed effects. P-values are displayed in brackets and based on robust standard errors.

There is a potential source of endogeneity in the exchange rate regime. A currency crisis and ensuing move from a pegged towards a flexible regime often occur months after the shock (typically the year after) when foreign reserves are depleted and the peg cannot be maintained any longer. A flexible exchange rate regime dummy could thus capture the effect of the preceding oil price slump ${ }^{27}$ and including time fixed effects would not solve the problem as the shock occurs in $t-1$. To exclude this possibility, we also perform the same regressions with a contemporary and lagged oil price instead of time fixed effect. The results of these regressions confirm the previous finding: more flexible exchange rate regimes seem to be associated with a lower long run GDP per capita compared to the one achieved with the fixed exchange rate regime (Table 14).

${ }^{27}$ Still a significant impact on GDP in case of a negative oil shock would be required which, on average, appeared to be the case only at $10 \%$ level in the previous analysis. 
Table 14. Impact of exchange rate regime controlling for oil price

\begin{tabular}{|c|c|c|c|c|c|c|}
\hline $\begin{array}{l}\text { Long-run } \\
\text { coefficients }\end{array}$ & Regime & Regime_Gov & Finance_Gov & Infl_Gov & Trade_Gov & Oils_Gov \\
\hline \multirow[t]{2}{*}{ Investment } & 0.339 & 0.295 & 0.372 & 0.313 & 0.245 & 0.190 \\
\hline & {$[0.149]$} & [0.169] & [0.153] & {$[0.177]$} & [0.195] & {$[0.219]$} \\
\hline \multirow[t]{2}{*}{ Education } & $0.258^{* * *}$ & $0.227^{\star *}$ & $0.230^{* *}$ & $0.181^{*}$ & $0.202^{\star *}$ & $0.116^{*}$ \\
\hline & {$[0.000]$} & {$[0.018]$} & {$[0.022]$} & {$[0.094]$} & {$[0.028]$} & {$[0.080]$} \\
\hline \multirow[t]{2}{*}{ Population } & $-0.559^{\star *}$ & $-0.516^{* *}$ & $-0.461^{*}$ & -0.242 & $-0.513^{* *}$ & $-0.514^{* *}$ \\
\hline & {$[0.046]$} & {$[0.046]$} & {$[0.085]$} & {$[0.404]$} & {$[0.034]$} & {$[0.017]$} \\
\hline \multirow[t]{2}{*}{ Crawling } & -0.117 & -0.100 & -0.129 & -0.016 & -0.069 & -0.077 \\
\hline & {$[0.426]$} & {$[0.442]$} & {$[0.332]$} & {$[0.907]$} & {$[0.567]$} & {$[0.455]$} \\
\hline \multirow[t]{2}{*}{ Managed } & -0.076 & -0.049 & -0.069 & -0.024 & -0.038 & 0.010 \\
\hline & {$[0.428]$} & {$[0.578]$} & {$[0.479]$} & {$[0.794]$} & [0.644] & {$[0.891]$} \\
\hline \multirow{2}{*}{ Flexible } & $-0.444^{* *}$ & $-0.344^{* *}$ & $-0.362^{* *}$ & $-0.295^{\star}$ & $-0.312^{* *}$ & $-0.213^{*}$ \\
\hline & {$[0.026]$} & {$[0.037]$} & {$[0.046]$} & {$[0.065]$} & {$[0.036]$} & {$[0.091]$} \\
\hline \multirow[t]{2}{*}{ Conflict } & -0.025 & -0.035 & -0.035 & 0.000 & -0.024 & 0.043 \\
\hline & [0.839] & [0.729] & {$[0.738]$} & {$[0.999]$} & {$[0.805]$} & {$[0.616]$} \\
\hline \multirow[t]{2}{*}{ Oil } & 0.094 & 0.054 & 0.004 & 0.029 & 0.050 & 0.105 \\
\hline & {$[0.258]$} & {$[0.467]$} & {$[0.953]$} & {$[0.692]$} & {$[0.456]$} & {$[0.110]$} \\
\hline \multirow[t]{2}{*}{ Crisis } & $-0.580^{* *}$ & $-0.637^{* *}$ & $-0.675^{\star \star}$ & $-0.658^{* *}$ & $-0.605^{* *}$ & $-0.479^{\star *}$ \\
\hline & {$[0.027]$} & {$[0.019]$} & {$[0.021]$} & [0.019] & {$[0.013]$} & {$[0.015]$} \\
\hline \multirow[t]{2}{*}{ Government } & & 0.072 & 0.117 & 0.145 & 0.119 & $0.291^{*}$ \\
\hline & & {$[0.779]$} & {$[0.656]$} & {$[0.590]$} & {$[0.615]$} & {$[0.100]$} \\
\hline \multirow[t]{2}{*}{ Finance } & & & -0.073 & & & \\
\hline & & & {$[0.227]$} & & & \\
\hline \multirow[t]{2}{*}{ Inflation } & & & & -0.004 & & \\
\hline & & & & {$[0.308]$} & & \\
\hline \multirow[t]{2}{*}{ Trade } & & & & & 0.002 & \\
\hline & & & & & [0.285] & \\
\hline \multirow[t]{2}{*}{ Share } & & & & & & $-0.007^{\star *}$ \\
\hline & & & & & & [0.013] \\
\hline \multirow[t]{2}{*}{ Constant } & $17.370^{\star \star *}$ & $15.312^{* *}$ & $13.504^{*}$ & 9.246 & $14.161^{* *}$ & $11.101^{* *}$ \\
\hline & {$[0.000]$} & {$[0.031]$} & {$[0.066]$} & [0.189] & {$[0.031]$} & {$[0.029]$} \\
\hline $\mathrm{N}$ & 494 & 494 & 472 & 478 & 494 & 486 \\
\hline ar2 & 0.349 & 0.386 & 0.391 & 0.353 & 0.385 & 0.394 \\
\hline
\end{tabular}

Note: All the regressions include country fixed effects. P-values are displayed in brackets and based on robust standard errors.

The typical explanations arguing in favour of a fixed exchange rate regime are well known. They usually refer to lower transaction costs which support foreign exchange of goods, services and capital, to a stabilised value of the external debt expressed in national currency and to anchored inflation expectations (Levy-Yeyati and Sturzenegger (2001), Ghosh and Ostry (2009)). In the case of oil exporters, the positive impact of the fixed exchange rate could also result from the role of sovereign wealth or stabilisation funds. Most oil exporters with a fixed exchange rate regime have introduced sovereign wealth funds which invest a part of oil revenues in foreign assets and draw down subject to substantial oil price shocks. If these funds are large enough, they allow insulating the economy against oil price fluctuations and help oil exporters to maintain a fixed exchange rate regime even in the long run without creating macroeconomic imbalances. For example, Mohaddes and Raissi (2017) find that having a sovereign wealth fund can mitigate negative growth effects of commodity price volatility. No detailed enough data on the behaviour of stabilisation funds 
are available to go further in the analysis of this question, but we believe that the role of stabilisation funds and the rules for the use of oil revenues should be the focus of future research.

\section{Concluding remarks}

This work has provided explicit evidence of the negative impact of oil dependence on economic development: on average, a 10-percentage point increase in oil exports share would lead to a 7\% lower GDP per capita in the long run. Implicitly, countries should diversify their exports and the overall economy, though this topic is beyond the scope of this work. Some institutional settings may be helpful for achieving this goal. In particular, results suggest that counter-cyclical fiscal policies coupled with a stable exchange rate protect the economy of oil dependent countries against oil price shocks and favour economic development. The channels linking exchange rate regimes and economic outcomes require more investigation. In particular, the role of stabilisation funds and wellestablished rule for the use of oil revenues should be the focus of future research. 


\section{Appendix}

Table 15. Variables and data sources

\begin{tabular}{|c|c|c|c|}
\hline Variable name & Description & Availability & Source \\
\hline GDP & Log of real GDP per capita PPP adjusted (2010) & $1960-2016$ & $\begin{array}{l}\text { Calculations based on World } \\
\text { Bank data }\end{array}$ \\
\hline INVESTMENT & Gross capital formation over GDP ratio & $1960-2015$ & World Bank \\
\hline EDUCATION & Educational attainment in population over age 15 & $1950-2010$ & Barro and Lee (2013) \\
\hline POPULATION & Log of total population & $1960-2015$ & World Bank \\
\hline GOVERNMENT & $\begin{array}{l}\text { Real Government consumption expenditure PPP } \\
\text { adjusted (2010) }\end{array}$ & $1960-2015$ & $\begin{array}{l}\text { Calculations based on World } \\
\text { Bank data }\end{array}$ \\
\hline OIL & Real average oil price of WTI, Brent and Dubai & $1960-2015$ & World Bank \\
\hline PRODUCTION & Log oil production (barrels per day) & $1980-2015$ & $\begin{array}{l}\text { Energy Information } \\
\text { Administration }\end{array}$ \\
\hline SHARE & Oil exports share in total exports & $1980-2012$ & WEO IMF \\
\hline FINANCE & Financial depth (M2 over M1 ratio) & $1960-2014$ & World Bank \\
\hline CONFLICT & $\begin{array}{l}\text { Dummy for conflict with more than } 25 \text { but less than } \\
1000 \text { battle deaths in a year }\end{array}$ & $1946-2014$ & $\begin{array}{l}\text { Harbom et al. (2012), Gleditch } \\
\text { et al. (2002) }\end{array}$ \\
\hline TRADE & $\begin{array}{l}\text { Trade openness (sum of exports and imports over } \\
\text { GDP) }\end{array}$ & $1960-2015$ & World Bank \\
\hline CAPITAL & Capital openness ( $0=$ high, $1=$ low $)$ & $1970-2014$ & Chinn and Ito (2006) \\
\hline FREEDOM & $\begin{array}{l}\text { Political rights and civil liberty index ( } 0=\text { not free, } \\
1=\text { free) }\end{array}$ & $1972-2016$ & Freedom House \\
\hline POLITY & Political regime $(-10=$ autocracy,$+10=$ democracy $)$ & $1800-2015$ & $\begin{array}{l}\text { Polity IV Project (Marshall et } \\
\text { al., 2017) }\end{array}$ \\
\hline JUDICIARY & Independent judiciary ( $0=$ dependent, $1=$ independent) & $1948-2012$ & Linzer and Staton (2015) \\
\hline EXPORTS & Real exports PPP adjusted (2010) & $1960-2016$ & $\begin{array}{l}\text { Calculations based on World } \\
\text { Bank data }\end{array}$ \\
\hline FOREX & Nominal exchange rate (national currency/USD) & $1960-2016$ & World Bank \\
\hline NEER & Nominal effective exchange rate & $1960-2016$ & Bruegel \\
\hline REER & Real effective exchange rate & $1960-2016$ & Bruegel \\
\hline D."x" & First difference of "x" & & \\
\hline
\end{tabular}


Table 16. Sovereign wealth funds

\begin{tabular}{|c|c|c|c|}
\hline Country & ISO & Inception & Fund name \\
\hline Algeria & DZA & 2000 & Revenue Regulation Fund \\
\hline Bahrain & $\mathrm{BHR}$ & & \\
\hline Brunei Darussalam & BRN & 1983 & Brunei Investment Agency \\
\hline Cameroon & CMR & & \\
\hline Canada & CAN & 1976 & Alberta's Heritage Fund \\
\hline Colombia & $\mathrm{COL}$ & 2011 & Colombia Savings and Stabilisation Fund \\
\hline Congo, Dem. Rep. & COD & & \\
\hline Congo & COG & & \\
\hline Ecuador & ECU & & \\
\hline Egypt & EGY & & \\
\hline Gabon & GAB & 1998 & Gabon Sovereign Wealth Fund \\
\hline Indonesia & IDN & & \\
\hline Kazakhstan & $\mathrm{KAZ}$ & 2000 & Kazakhstan National Fund \\
\hline Kuwait & KWT & 1953 & Kuwait Investment Authority \\
\hline Libya & LBY & 2006 & Libyan Investment Authority \\
\hline Malaysia & MYS & & \\
\hline Mexico & MEX & 2000 & Oil Revenues Stabilisation Fund of Mexico \\
\hline Norway & NOR & 1990 & Government Pension Fund - Global \\
\hline Papua New Guinea & PNG & 2011 & Papua New Guinea Sovereign Wealth Fund \\
\hline Russia & RUS & 2008 & National Welfare Fund \\
\hline Saudi Arabia & SAU & 1952 & SAMA Foreign Holdings \\
\hline Trinidad and Tobago & TTO & 2000 & Heritage and Stabilisation Fund \\
\hline United Arab Emirates & ARE & 1976 & Abu Dhabi Investment Authority \\
\hline Yemen & YEM & & \\
\hline
\end{tabular}

Source: Sovereign Wealth Fund Institute. 
Table 17. Baseline growth regression

\begin{tabular}{|c|c|}
\hline Variable & Baseline \\
\hline L.GDP & $\begin{array}{c}-0.080^{* * *} \\
{[0.000]}\end{array}$ \\
\hline L.Investment & $\begin{array}{c}0.030^{* \star *} \\
{[0.009]}\end{array}$ \\
\hline L.Education & $\begin{array}{c}0.006 \\
{[0.414]}\end{array}$ \\
\hline L.Population & $\begin{array}{c}-0.076^{* \star *} \\
{[0.001]}\end{array}$ \\
\hline D.Investment & $\begin{array}{c}0.028 \\
{[0.175]}\end{array}$ \\
\hline D.Education & $\begin{array}{l}-0.003 \\
{[0.872]}\end{array}$ \\
\hline D.Population & $\begin{array}{c}-1.151^{* * *} \\
{[0.000]}\end{array}$ \\
\hline Conflict & $\begin{array}{l}-0.000 \\
{[0.948]}\end{array}$ \\
\hline Constant & $\begin{array}{l}1.944^{* * *} \\
{[0.000]}\end{array}$ \\
\hline$N$ & 512 \\
\hline ar2 & 0.383 \\
\hline
\end{tabular}

Note: The coefficients are displayed without long run impact transformation. The regression includes country fixed effects. P-values are displayed in brackets and based on robust standard errors. 


\section{References}

Acemoglu, D., Naidu, S., Restrepo, P., \& Robinson, J. (2014). Democracy does cause growth. National Bureau of Economic Research.

Andersen, J., \& Aslaksen, S. (2013). Oil and political survival. Journal of Development Economics, 100(1), 89-106.

Arezki, R., \& Van der Ploeg, F. (2011). Do natural resources depress income per capita? Review of Development Economics, 15(3), 504-521.

Auty, R., \& Warhurst, A. (1993). Sustainable development in mineral exporting economies. Resources Policy, 19(1), 14-29.

Balli, H., \& Sørensen, B. (2013). Interaction effects in econometrics. Empirical Economics, 1-21.

Beck, N., \& Katz, J. (2011). Modeling dynamics in time-series-cross-section political economy data. Annual Review of Political Science, 14, 331-352.

Cavalcanti, D., Tiago, V., Mohaddes, K., \& Raissi, M. (2015). Commodity price volatility and the sources of growth. Journal of Applied Econometrics, 30(6), 857-873.

Chinn, M., \& Ito, H. (2006). What matters for financial development? Capital controls, institutions, and interactions. Journal of development economics, 81(1), 163-192.

Collier, P., \& Hoeffler, A. (1998). On economic causes of civil war. Oxford economic papers, 50(4), 563-573.

Frankel, J. (2012). The natural resource curse: a survey of diagnoses and some prescriptions.

Ghosh, A., Ostry, J., \& Qureshi, M. (2015). Exchange rate management and crisis susceptibility: A reassessment. IMF Economic Review, 63(1), 238-276.

House, F. (2016). Freedom in the World 2016: The Annual Survey of Political Rights and Civil Liberties. Rowman \& Littlefield.

Jensen, N., \& Wantchekon, L. (2004). Resource wealth and political regimes in Africa. Comparative political studies, 37(7), 816-841.

Kao, C. (1999). Spurious regression and residual-based tests for cointegration in panel data. Journal of econometrics, 90(1), 1-44.

Linzer, D., \& Staton, J. (2015). A global measure of judicial independence, 1948-2012. Journal of Law and Courts, 3(2), 223-256.

Mankiw, N., Romer, D., \& Weil, D. (1992). A contribution to the empirics of economic growth. The quarterly journal of economics, 107(2), 407-437.

Marshall, M., Jaggers, K., \& Gurr, T. (2012). Political regime characteristics and transitions, 18002008, Polity IV Project. Fairfax County: Center for Systemic Peace.

Matsuyama, K. (1992). Agricultural productivity, comparative advantage, and economic growth. Journal of economic theory, 58(2), 317-334.

Mehlum, H., Moene, K., \& Torvik, R. (2006). Institutions and the resource curse. The economic journal, 116(508), 1-20.

Mork, K., Olsen, Ø., \& Mysen, H. (1994). Macroeconomic responses to oil price increases and decreases in seven OECD countries. The Energy Journal, 19-35.

Nickell, S. (1981). Biases in dynamic models with fixed effects. Econometrica: Journal of the Econometric Society, 1417-1426.

Pesaran, M. (1997). The role of economic theory in modelling the long run. The Economic Journal, 107(440), 178-191.

Ross, M. (2012). The oil curse: how petroleum wealth shapes the development of nations. Princeton University Press.

Ross, M. (2015). What have we learned about the resource curse? Annual Review of Political Science, $18,239-259$.

Sachs, J., \& Warner, A. (1995). Natural resource abundance and economic growth. National Bureau of Economic Research.

Smith, R., \& Fuertes, A.-M. (2010). Panel time-series. 
Tornell, A., \& Lane, P. (1999). The voracity effect. american economic review, 22-46.

Wiens, D. (2014). Natural resources and institutional development. Journal of Theoretical Politics, 26(2), 197-221. 